\title{
Understanding the Impacts of Blue Economy Growth on Deep-Sea Ecosystem Services
}

\author{
Nezha Mejjad ${ }^{1, *(D)}$ and Marzia Rovere ${ }^{2, *(D)}$ \\ 1 Department of Geology, Faculty of Sciences Ben M'sik, University Hassan II, Casablanca 20670, Morocco \\ 2 Institute of Marine Sciences, National Research Council, Via P. Gobetti 101, 40129 Bologna, Italy \\ * Correspondence: mejjadnezha@gmail.com (N.M.); marzia.rovere@bo.ismar.cnr.it (M.R.)
}

\footnotetext{
check for updates

Citation: Mejjad, N.; Rovere, M. Understanding the Impacts of Blue Economy Growth on Deep-Sea Ecosystem Services. Sustainability 2021, 13, 12478. https://doi.org/ $10.3390 /$ su132212478
}

Academic Editor: Just Tomàs Bayle-Sempere

Received: 11 October 2021

Accepted: 28 October 2021

Published: 11 November 2021

Publisher's Note: MDPI stays neutral with regard to jurisdictional claims in published maps and institutional affiliations.

Copyright: (c) 2021 by the authors. Licensee MDPI, Basel, Switzerland. This article is an open access article distributed under the terms and conditions of the Creative Commons Attribution (CC BY) license (https:/ / creativecommons.org/licenses/by/ $4.0 /)$.

\begin{abstract}
The deep sea is the vastest environment on Earth and provides many services and goods. Understanding the services and goods of deep-sea ecosystems would enable better resource governance and decision-making. In the present study, we reviewed and assessed deep-sea ecosystems services using the Ma conceptual framework, which incorporates ecosystems services and goods with human welfare. We also analyzed and measured the scientific production between 2012 and 2021 using the Dimension dataset. The bibliometric analysis showed a lack of studies related to deep-sea ecosystem services, which suggest the urgent need to overcome the existing knowledge gap regarding deep-sea components. However, the current knowledge revealed the crucial role that these ecosystems provide to the planet. Furthermore, we highlighted that there are common services and goods, and every ecosystem service feeds into another one. Developing actions and policies based on approaches that combine all deep-sea ecosystems services and goods are needed for the sustainable growth of the deep-sea economy in accordance with the United Nations Development Goal 14: Life Below Water.
\end{abstract}

Keywords: Ma conceptual framework; Dimensions; bibliometric study; ocean conservation; environmental impact assessment; sustainable growth; blue economy

\section{Introduction}

The deep sea is the most extensive environment on the Earth and is defined as the water column and seafloor below $200 \mathrm{~m}$ water depth [1]. Until the first half of the 19th century, the ocean was considered devoid of life below $500 \mathrm{~m}$ and was viewed as a dark, huge and inhabitable environment. The subsequent outstanding scientific discoveries have not only shown that the ocean is the largest biome on Earth but also that the deep sea plays a crucial role as it provides many ecosystem services and goods by driving the global biogeochemical cycle of elements and nutrient regeneration [2-5], which allows the ocean to maintain its primary and secondary production [6,7]. In addition, the deep sea contains a wide variety of habitats (e.g., abyssal plains, mid-ocean ridges, seamounts, canyons, hydrothermal vents, mesophotic and deep-water coral reefs and cold seeps) and supports the highest biodiversity of species on Earth [8,9].

The deep seafloor also presents many resources, including fish, gene mines, oil, gas and metals of economic interest. Therefore, the deep sea provides highly valuable services for human well-being [10-12]. Understanding the importance of every component of deep-sea ecosystems can help to overcome the existing gap in knowledge, especially under the continuous growth of human activities in the deep sea, which requires the assessment of their impacts on the overall ecosystem health.

The ecosystem services (E.S.) concept comprises ecological functions (e.g., climatic adaptation) and social and economic values (e.g., food security, job creation) that promote human well-being. This approach has been applied, for example, to assess the value and quantify the E.S. of lagoons and wetlands, as well as to coastal water management [13-19]. Even though the deep sea represents the largest ecosystem [20], few studies have attempted to apply and assess E.S. there [4,11,21]. 
Deep-sea E.S. comprise the provisioning of services as discussed above, such as industrial agents and fish catch, regulating services such as climatic and biological regulation and cultural services such as aesthetics and inspiration for the arts. Several studies have shown that deep-sea ecosystems support a large variety of habitats and a wide array of faunal communities with various functions. These complex communities are threatened by the growth of human activities targeting precisely these provided ecosystem services [22]. For instance, it was reported by UNEP [23] that 6.4 million tonnes of litter enter the ocean yearly; this waste can float in the water surface and accumulate on the deep-sea floor as the final global receptor of microplastics [24]. A high density of litter is found in submarine canyons while waste resulting from fishing activities is common on ocean ridges, seamounts, banks and mounds according to a study carried out in European seas [25]. The considerable amounts of litter accumulating from human activities most certainly have harmful impact on marine habitats, communities and functions.

Similarly, bottom-trawling is reported as a harmful activity, causing habitat destruction and fauna loss (target and non-target species), such as in seamounts where communities of sessile fauna are heavily affected by bottom-trawling [26]. Deep-sea oil and gas drilling infrastructures are also reported to have effect on different size classes of the benthic community including meio-, macro- and megafauna, leading to changes in diversity, density and biomass [27]. However, insufficient knowledge regarding life below $200 \mathrm{~m}$ (e.g., habitat distribution, species identities, ecosystem function and structure, etc.) make the impact assessment of hydrocarbon exploitation very difficult.

To date, few studies have investigated deep-sea ecosystem services compared to shallower water. According to Jobstvogt et al. [10], there is a vast gap between the considerable concern that deep-sea scientists have and the transfer of this knowledge and understanding to decision makers and the wider public. The same authors link this gap of knowledge to the complexity of the marine ecosystem and a lack of awareness toward deep-sea environments and ecology. In the present study, we sought to fill the existing gap by analyzing and synthesizing the available scientific literature and identifying the services and goods provided by the deep sea, which allows us to define the social and economic value of deep-sea conservation. Such knowledge will be useful for assessing how economic activities (e.g., oil and gas exploitation) may disturb the physical and biological marine environment.

Therefore, we investigated the available literature related to deep-sea ecosystems services and goods in order to:

- $\quad$ provide an overview of the studies focused on deep-sea E.S. carried out between 2012 and 2021 using VosViewer, a bibliometric tool;

- review and define the deep-sea services and goods;

- define the potential impact of provisioning services on biodiversity and functions;

- combine and assess the impact of deep-sea products used by humans on supporting, regulating and cultural services.

\section{Materials and Methods}

\subsection{Bibliometric Analysis}

\subsubsection{Dimensions}

In the bibliometric analysis of the present study, the database was sourced from Dimensions (https:/ / www.dimensions.ai /, accessed on 7 August 2021). We have chosen this bibliographic database because it provides big data and is considered an excellent alternative to Web of Science (WoS) and Scopus in terms of coverage of many subject types [28]. Dimensions covers above 105 million publications [29] and other types of records, including patents, awarded grants, clinical trials, scientific publications (papers, books, chapter books and conferences proceedings), policy reports and Altmetric attention data [30].

The Dimensions database was launched in 2018 by Digital Sciences [30]. This database uses a freemium model where the browsing functionalities and basic search are free and accessible, while advanced functionalities such as application programming interface (API) access 
are premium [28]. Several recent bibliometric studies were carried out by using Dimensions as a source for analyzing literature data and comparing different databases [28,29,31-34].

The parameters of our search query are as follows:

- Date range: 2012-2021;

- Publication type: "article", "policy document", "chapter", "articles", "edited book", "proceeding", "preprint";

- $\quad$ The query search was performed on 8 August 2021.

The number of publications in each category recorded between 2012 and 2021 for the research fields related to deep-sea ecosystem services are mainly the biological, environmental and Earth sciences, as shown in Figure 1. This reflects the growing interest in studying the biological and environmental aspects of the deep sea.

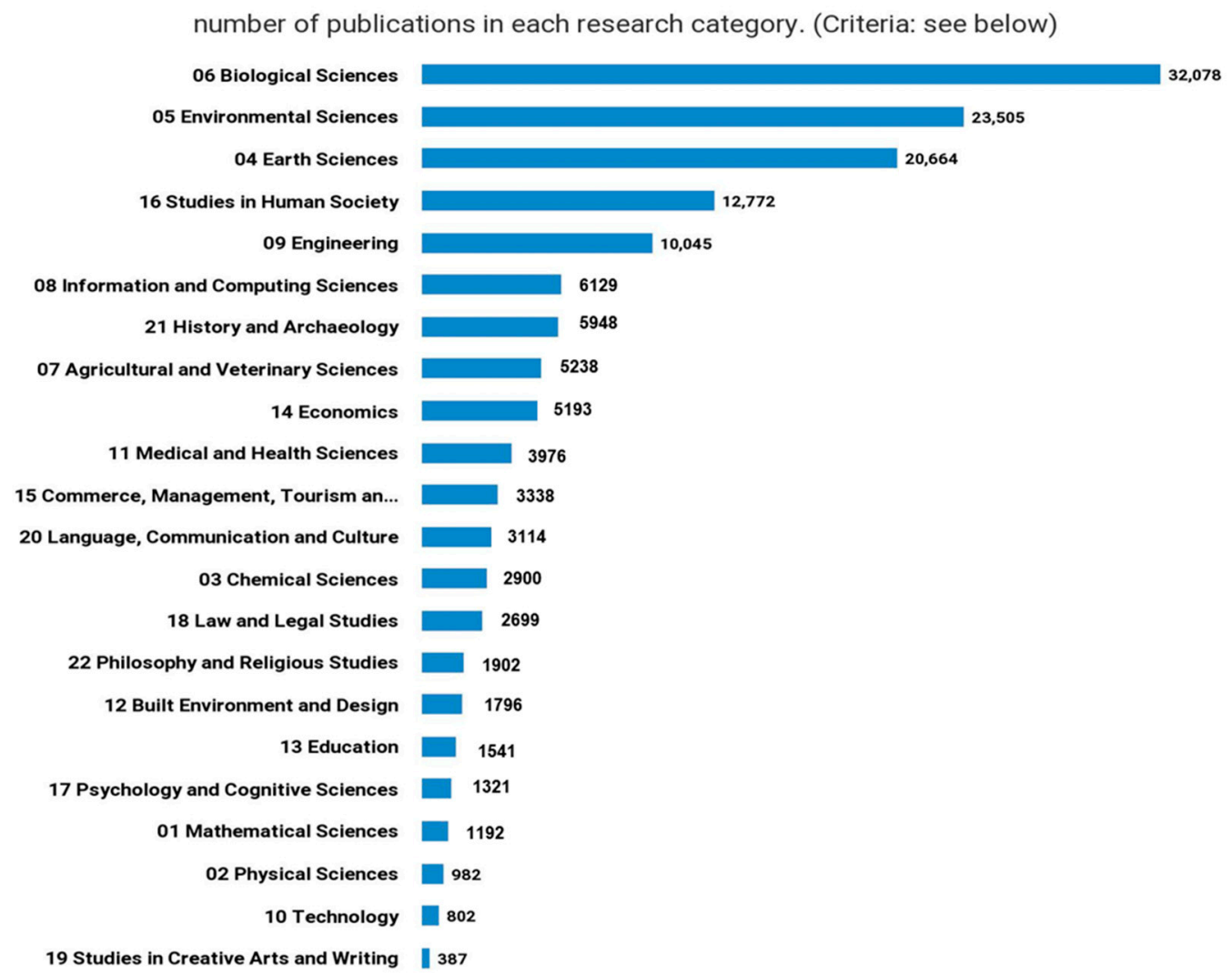

Figure 1. Free screenshot of number of publications in each research category, source: https:/ /app. dimensions.ai. Exported 9 August 2021. Criteria text: "deep sea ecosystem services" in full data. Publication Year: 2012-2021.

\subsubsection{VOSviewer}

VOSviewer (https:/ / www.vosviewer.com/, accessed on 7 August 2021) is a software intended to analyze bibliometric networks and create maps based on these networks, allowing the user to visualize and explore these maps according to the network data [35]. A map can be established based on already available network data. The software can construct networks of scientific journals, publications, researchers, research organizations, countries, terms or keywords. To build the networks, bibliographic database files (such as Scopus, Web of Sciences, Dimensions, lens, etc.) and reference managers (such as EndNote, RefWorks files) can be provided as input to VOSviewer.

VOSviewer provides three visualizations maps: (i) the network visualization, (ii) the overlay visualization, and (iii) the density visualization. 


\subsection{Literature Review}

In addition to the use of the Dimensions database, we conducted a literature review by utilizing available online databases and internet search tools including Science Direct, WoS, Researchgate and Google Scholar to build a bibliographic database based on peerreviewed scientific publications, theses and non-peer-reviewed consultancy, books, policy and technical policy reports comprised of 200 files and documents. The literature search was initially focused on studies related to anthropogenic disturbances and environmental impact assessment of human activities in the deep sea and then was narrowed down on each deepsea ecosystem service and the impact of every provisioning service on supporting, regulating and cultural services. Therefore, we conducted the searches by using the keywords "deepsea", "ecosystem services", "blue growth" and "pollution impact". The keywords were utilized either in combination or singularly. As mentioned above, information was retrieved from different databases and also from the International Seabed Authority (ISA) technical and policy reports and the International Union for Conservation of Nature (IUCN) web resources, which contained data and information relevant to this study.

\subsection{Ma Conceptual Framework}

The Millennium Ecosystem Assessment (Ma) is a conceptual framework established with the participation of governments, non-governmental organizations, the private sector and scientists to deliver an integrated assessment of the consequences of ecosystem changes on human well-being. Other frameworks for the classification and identification of ecosystem services were developed after the establishment of the Ma framework [36] such as the UN Common International Classification of Ecosystem Services (CICES), the Economics of Ecosystems and Biodiversity (TEEB) and the Intergovernmental Platform on Biodiversity and Ecosystem Services (IPBES) [37-39].

Thus, the Ma conceptual framework was designed to assess ecosystems that integrate ecosystems services and goods with social systems [36] and investigate the available options to improve the conservation and maintenance of ecosystems services and goods. The Ma conceptual framework has allowed reviewing, examining and understanding how environmental changes can affect the ecosystem and human welfare [40]. This ecosystem services framework was widely used in publications related to the assessment of the marine ecosystem services and human welfare $[3,10,37,41-43]$, but it is narrowly applied to the deep-sea environment. The Ma framework includes four categories (Figure 2): supporting (e.g., primary production, photosynthesis, nutrient cycling), provisioning (e.g., food, genetic resources), regulating (e.g., climate regulation, pollination, natural hazards regulation) and cultural services (e.g., spiritual and religious value, educational value) [36,44].

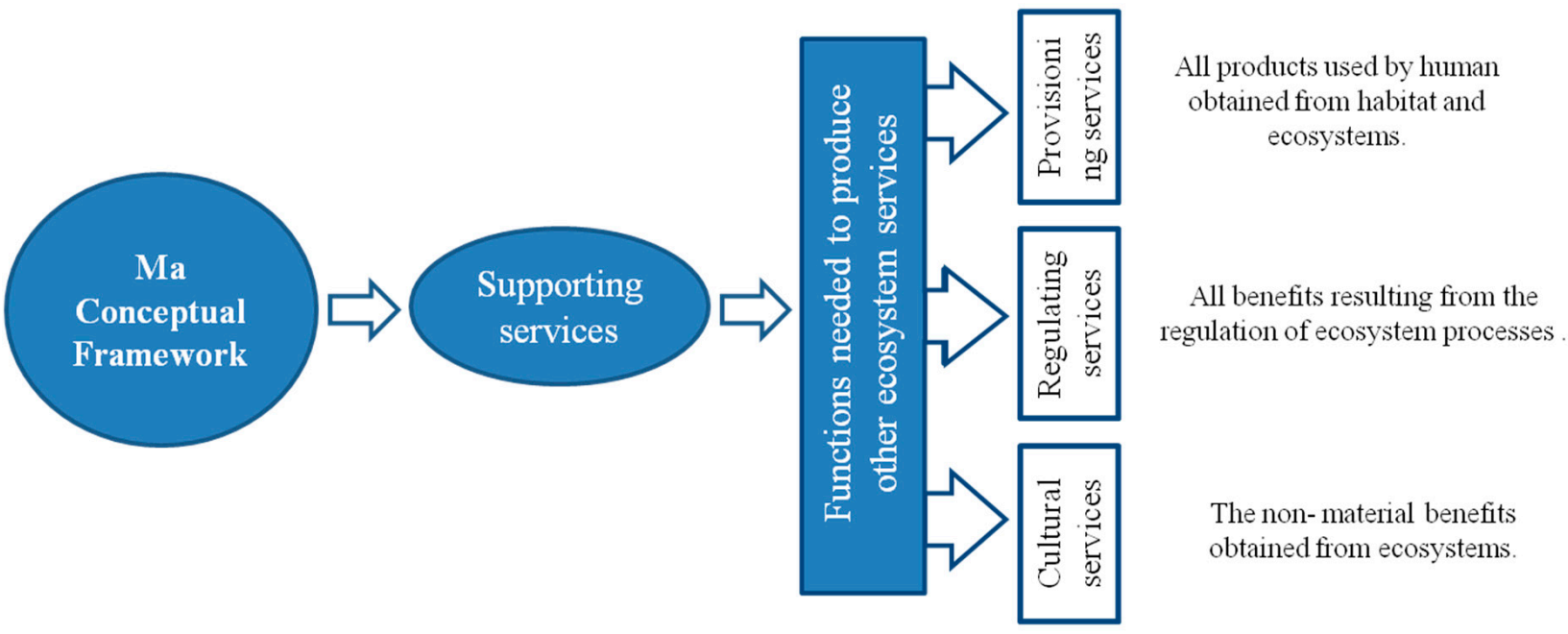

Figure 2. Description of the four categories of the Ma conceptual Framework (adapted from Ma, 2005) [36]. 


\section{Results}

\subsection{Bibliometric Analysis Using VOSviewer}

A total of $95 \%$ (215,128 publications) of the publications relating to our search query in Dimensions were book chapters, articles, edited books, monographs, proceedings, preprints, policy documents, patents and datasets (Figure 3). A total of 48,135 research studies were published in 199 journals, mostly in PLOS One $(\mathrm{N}=1538 ; 3 \%)$, Science of the Total Environment $(\mathrm{N}=1472 ; 3 \%)$; Lecture Notes in Computer Science $(\mathrm{N}=122 ; 2 \%)$; and Frontiers in Marine Science ( $\mathrm{N}=1219 ; 2 \%)$. These results are consistent with Costa et al. (2020) [45], who analyzed deep-sea biodiversity using the science mapping approach to provide a systematic and global bibliometric analysis about the studied topic.

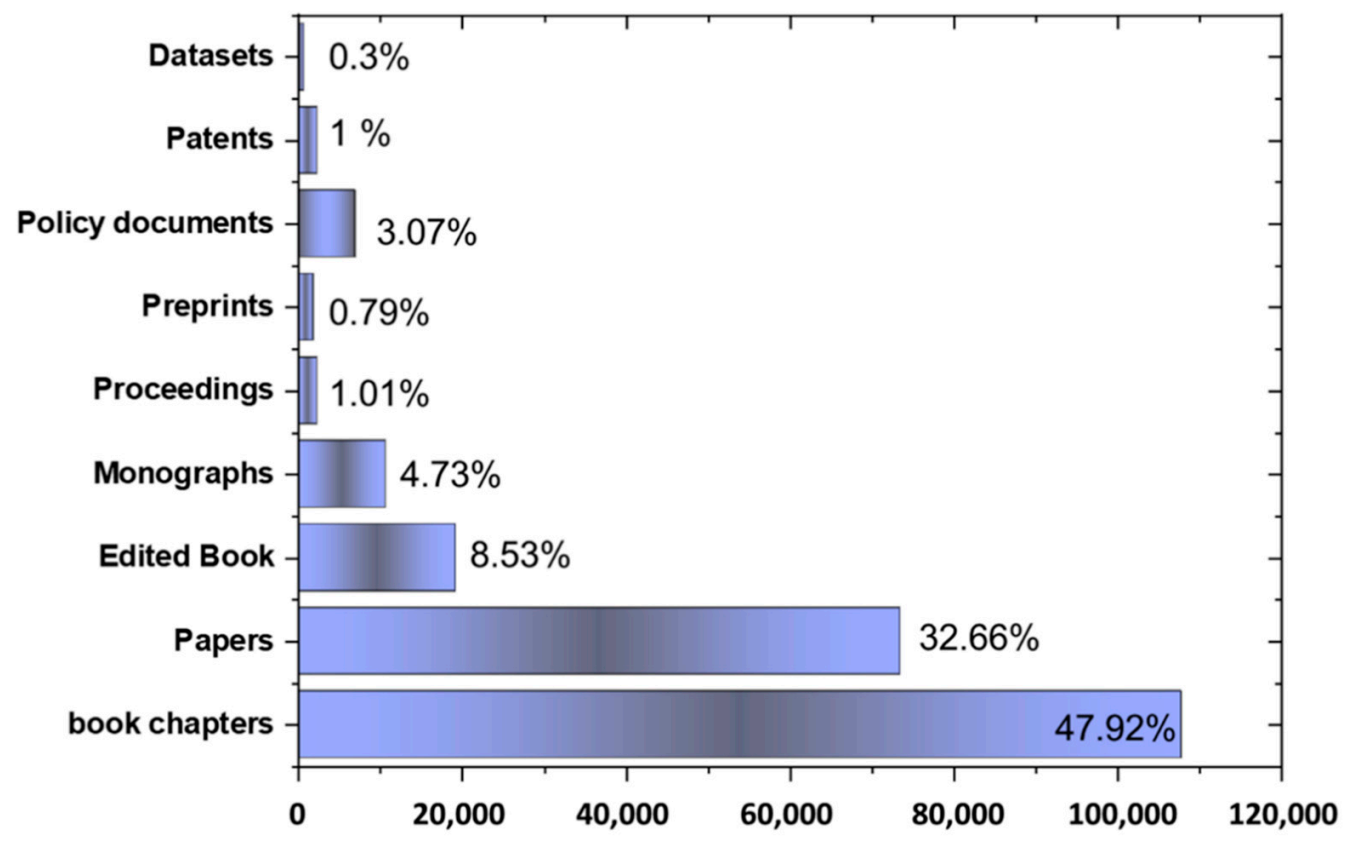

Figure 3. The percentage and type of documents corresponding to our search query for deep-sea and ecosystem services.

The visualization map of the documents published between 2012 and 2021 (Figure 4a) shows the range of keywords and their co-occurrences related to deep-sea ecosystem services. Co-occurrences are utilized to understand the underlying patterns of the document set under investigation [46].

In total, 291 terms were presented and grouped into 5 clusters, with 29,643 links and a total link strength of 307,534 . The main keyword co-occurrences for the red cluster (red circles in Figure 4a) are management (co-occurrence: 611), approach (co-occurrence: 654), ecosystem services (co-occurrence: 562) and assessment (co-occurrence: 475), followed by the green circles, for which the main keywords are diversity (co-occurrence: 636), abundance (co-occurrence: 592), concentration (co-occurrence: 565) and sediment (cooccurrence: 480). The main topic corresponding to the third cluster (blue circles) is climate change, where the main keywords are temperature (co-occurrence: 478 ) and warming (cooccurrence: 122). The main keywords related to the yellow cluster are carbon sequestration (co-occurrences: 240) and sea-level rise (co-occurrences: 176). The fifth cluster is mainly related to biodiversity (co-occurrence: 566 ), biomass (co-occurrence: 400 ) and ecosystem function (co-occurrence: 218).

Each cluster covers the following topics:

(i) The ecosystem services and goods, management and assessment tools and approaches cluster (red cluster in Figure 4a; 98 terms) reveals that the studies on ocean governance and conservation and the assessment of deep-sea ecosystem services are relatively advanced. Such studies mainly focus on laws and regulations regarding the exploration and exploitation of deep-sea resources, especially oil and gas and deep-sea minerals. How- 
ever, the occurrence of keywords such as "knowledge" (co-occurrence: 286), "knowledge gap" (co-occurrence: 58), "gap" (co-occurrence: 110), "challenge" (co-occurrence: 242) and "uncertainty" (co-occurrence: 111) demonstrate that researchers are still investigating how to overcome the lack of knowledge related to the field of "deep-sea ecosystem services", which is the main concern against, for instance, the development of deep-sea mining.

(ii) The deep-sea sediments, contamination and microplastic pollution cluster (green cluster in Figure 4a; 82 terms) mainly refers to studies related to deep-sea sediments analysis and contamination assessment. Such studies focus on texture, organic matter; carbonate content, geochemical composition (e.g., heavy metals), oil spills and contamination and nano- and micro-plastic pollution in deep-sea sediments.

(iii) The deep-sea role in climate change mitigation, ocean warming and temperature increase impact on marine animals cluster (blue cluster in Figure 4a; 67 terms) groups studies related to climate change impact on deep-sea fauna (e.g., migration, mortality rate). In particular, these studies aim to evaluate the impact of climate change on the Antarctic deep-sea life.

(iv) The fourth cluster (yellow cluster in Figure 4a; 31 terms) is about the impact of ocean chemistry variability and sea-level rise on carbon cycling, using sediment cores and stable isotopes to highlight changes and variations of the global carbon cycle.

(v) The biomass and biodiversity cluster (purple cluster in Figure 4a; 13 terms) identifies scientific research carried out to understand the ecosystem functioning by analyzing the species richness and composition.

Figure $4 \mathrm{~b}$ displays the network map of the topic trend based on the keywords used from 2017 to 2021. This map is called overlay visualization, and the color bar shows the current scientific production. Purple keywords (e.g., ecosystem services, biodiversity) have been published in 2017, while green circles show that terms such as sediment, concentrations, abundance and conservation characterize the research work published in 2018. The more recently published works (between 2019 and 2020) mainly focus on micro-plastics, pollution and bacterial communities. However, the studies published in 2019 and 2020 show a small size circle reflecting the slight weight of items (keywords), which means that these fields are not well-studied while their occurrence proves there is a trend toward studies on micro-plastic pollution.

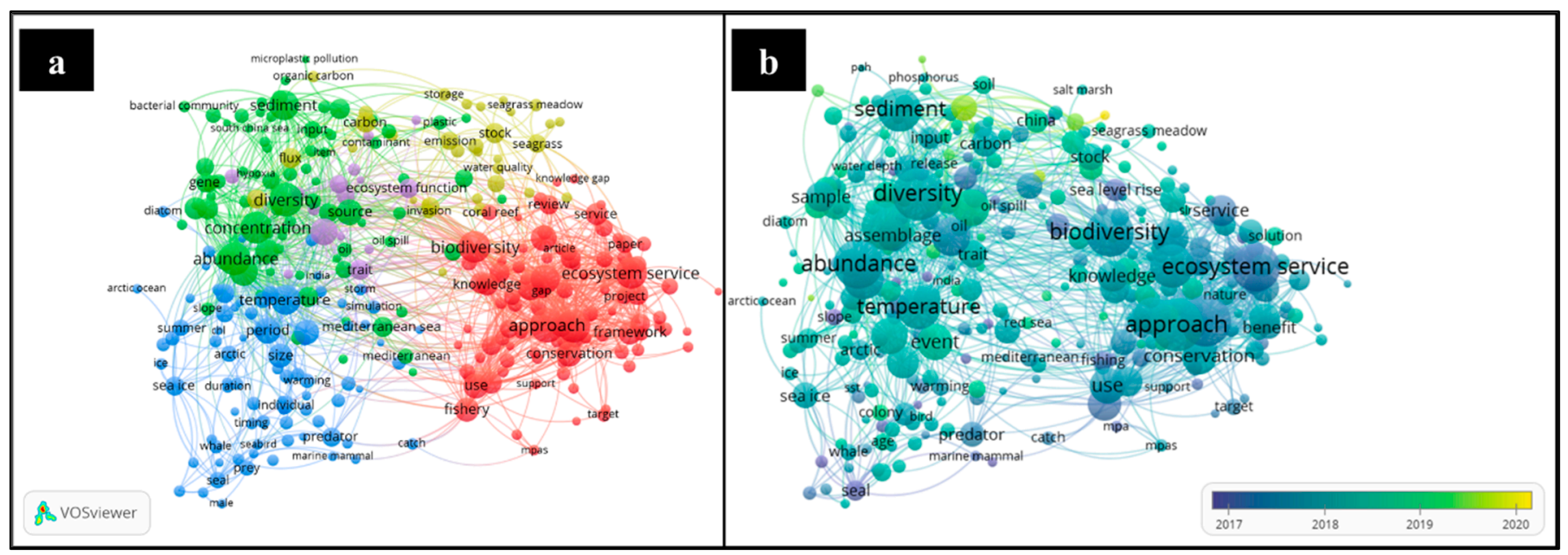

Figure 4. (a) Visualization map based on publication-weights, (b) visualization overlay map showing the current scientific production (2017-2021). The circle size is proportional to the number of published studies related to the items (terms or keywords), while the line represents the link between every item. The link between every term is strong when the line is short.

Figure 5 presents the density view map of the most important keywords related to deep-sea ecosystem services. Each keyword density relies upon the weight and number of neighboring keywords. Accordingly, a greater number of neighboring keywords and shorter distances between them indicate higher density, which results in a more intense 
color [35]. The keywords "ecosystem services", "abundance" and "approach" present high density, indicating that these keywords have a strong link with other keywords. In other words, this suggests that the higher the density, the more advanced and well-studied the research on that specific topic is [47-49]. In addition, it is reasonable to assume that the concern and requests for the management and conservation of deep-sea ecosystem services and goods are continually growing. Few keywords occupy the red area; almost all the keywords occupy orange and green areas, including "deep-sea", suggesting that the main research fields are very few.

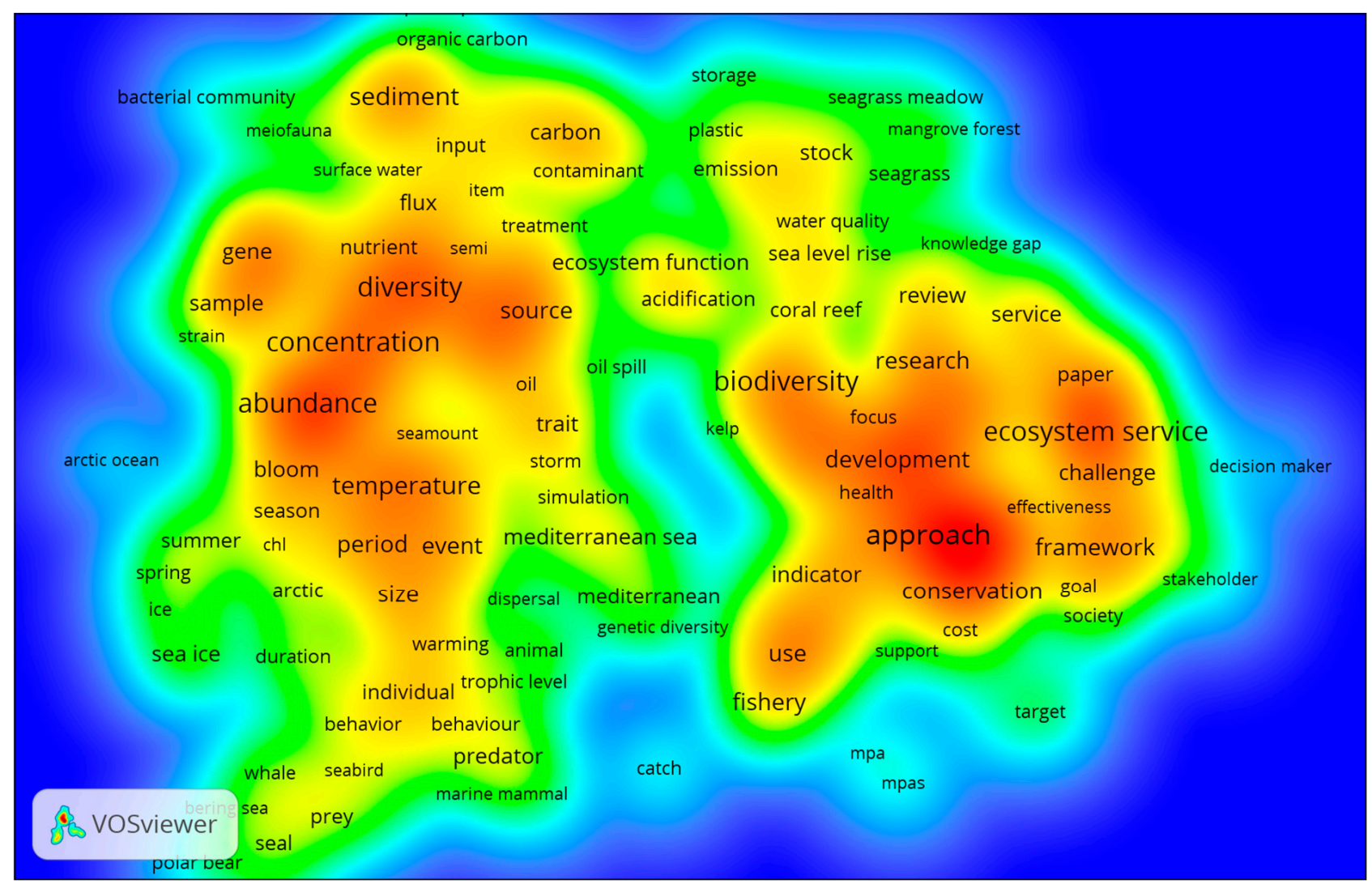

Figure 5. Density view map based on total link-weights.

It is worth noting that in comparison with the visualization map, we found that our research query "ecosystem services" (co-occurrence: 562) is linked to keywords "management", "conservation", "restoration", "challenge" and "gap knowledge", among others, with 282 links and a total links strength of 9601. The item "deep-sea" (co-occurrence: 133) is mainly linked to the keywords "gene", "taxa" and "depth", with 220 links and a total link strength of 1909.

\subsection{Evaluation of Deep-Sea Services}

Deep-sea goods and services must be first identified and characterized in order to quantify their benefits for human well-being. Human profit should note the environmental component given that any change in an ecosystem will affect the sustainability of the provided services and goods. As previously said, few studies have examined deep-sea services because of the knowledge gap related to the functions, biodiversity and life in deepsea ecosystems. The first study that analyzed deep-sea services and goods was carried out by Armstrong et al. [4] and highlighted the crucial role played by the deep sea in the global biogeochemical cycle. Jobstvogt et al. [10] reported the need for a better communication of the deep-sea ecological value to decision makers and the wider public for achieving ocean conservation targets, especially considering the general lack of knowledge and awareness about the deep-sea environment. 
Currently, there is an increasing interest in exploring and exploiting deep-sea resources such as minerals, which carry a considerable economic potential [50-53]. Thus, defining the supporting services of the deep-sea ecosystem that include habitats (e.g., seamount, abyssal plain, etc.) and biogeochemical cycling will allow researchers to quantify, on one hand, the benefits of these ecosystems and, on the other hand, to predict the potential risk of products used by humans and obtained from the habitat (provisioning services) such as the extraction of minerals.

As illustrated in Figure 6, deep-sea ecosystems provide a wide variety of services to human welfare, which supports direct (provisioning, regulating and cultural services) and indirect (supporting services) services [4].

\subsubsection{Supporting Services}

Habitat

The deep sea is the most extensive habitat and covers about 300 million $\mathrm{km}^{2}$ and provides a wide variety of physical habitats such as abyssal plains, hydrothermal vents and seamounts [54], where millions of known and unknown species live. Consequently, the estimation of the number of species living in the deep sea is unattainable due to the lack of knowledge related to the ecology and biodiversity of the deep sea. However, the development of technologies used in ocean exploration is supposed to increase the species discovery trend [55] in the near future, and the number of the known deep-sea species is predicted to soon exceed coastal areas [56]. Indeed, the newly available methods and technologies have allowed the discovery of novel species at an important rate in mesophotic coral ecosystems, which physically link shallow with deep-sea habitats and host various depth-generalist and specialist taxa [57].

\section{Nutrient Cycling}

Nutrient cycling is defined as the storage and recycling of nutrients within ecosystems by living organisms [58], where the nutrients regenerate via microbial respiration reactions in the deep ocean. These processes play a critical role in the global biogeochemical cycles, as they are indispensable for the primary production in the ocean photic zone [59].

\section{Chemosynthetic Primary Production}

Deep-sea ecosystems depend on chemosynthetic primary production (CPP), which consists in the formation of biological material through an accumulation of nutrients, energy and inorganic carbon $\left(\mathrm{C}_{\text {inorg }}\right)$ by organisms [4] and fuels highly productive invertebrate communities on the seafloor [60]. Because of the deep ocean conditions (e.g., absence of sunlight), some organisms (chemosynthetic bacteria and archaea) can use the chemical energy to convert $C_{\text {inorg }}$ into biomass. These energy sources occur only in a few places, such as tectonically active sites (e.g., mid-oceanic ridges), where seawater interacts with reactive minerals or with magma [61], creating hydrothermal vents or in methane seeps hosted on many continental margins [62-64].

\subsubsection{Provisioning Services}

As described previously, provisioning services are the products utilized by humans and obtained from habitats and ecosystems. In the case of the deep sea, these services include fisheries, abiotic resources (oil and gas/minerals) and waste disposal sites. 


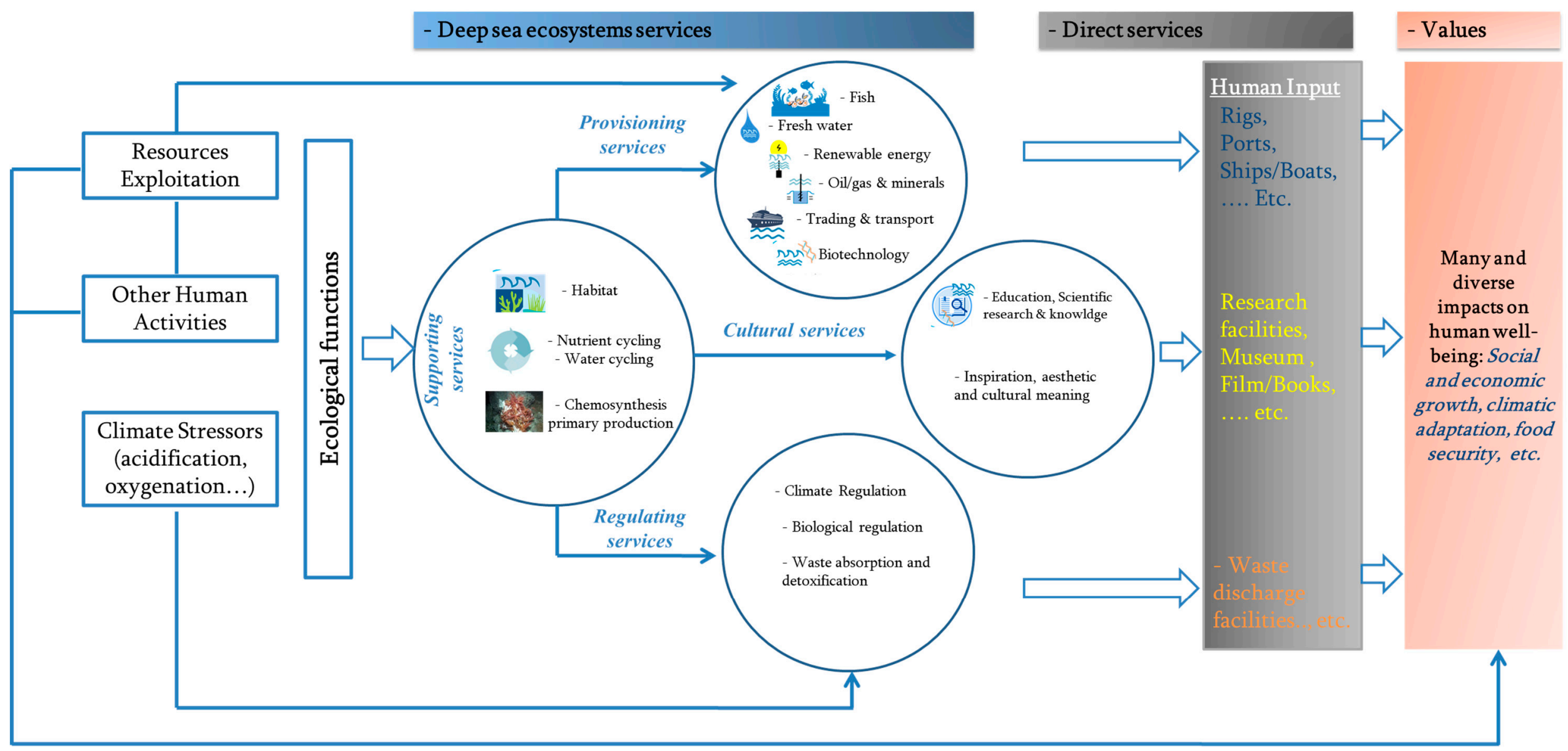

Figure 6. Deep-sea ecosystem goods and services (modified, source [36]). 
Fish

According to Gordon [65], there are three main categories of deep-water fish: (i) mesopelagic fish that live in the water column from beneath the photic zone to approximately $1000 \mathrm{~m}$ depth; (ii) bathypelagic fish, which are known by their adaptability to the food-poor environment and live in the zone below $1000 \mathrm{~m}$; and (iii) benthopelagic fish that live on or close to the bottom [4]. Currently, the blue ling, roundnose grenadier and Greenland halibut are the most exploited benthopelagic species. Other pelagic species that feed beneath $200 \mathrm{~m}$ are also commercially exploited, such as black scabbard fish, bigeye tuna and swordfish. Deep-sea species are slow-growing, long-living and have a low capacity of reproduction [66,67], therefore, these stocks can rapidly deplete and recover slowly. Consequently, the commercial harvesting of deep-sea fish is becoming unsustainable similarly to mineral mining [68].

\section{Oil and Gas}

Oil and gas in the deep sea belong to the ecosystem goods formed through geochemical processes over geological time. The depletion of oil and gas resources on land increased the global demand and need, while the technological advancements have expanded the offshore oil and gas industry into deeper water since 1960. Currently, drilling for oil and gas is routinely performed in waters $>200 \mathrm{~m}$ in offshore Australia, Southeast Asia, India, South America, the Gulf of Mexico, the northern Atlantic Ocean and the Arctic Ocean [69]. The major oil and gas reserves occur in water depths greater than $3000 \mathrm{~m}$ (i.e., ultra-deep water), and the most recent top reservoir discoveries are found in deep-water areas [70]. In the Gulf of Mexico, oil and gas exploitation takes place in waters exceeding $3000 \mathrm{~m}$ [71,72], while in offshore Angola, Total is preparing to establish a new record offshore well at a water depth of $3628 \mathrm{~m}$ [73]. The hydrocarbon exploitation in deep water is expected to expand more and more in the coming years, especially with the improvement of technology.

\section{Deep-Sea Minerals}

In the few research studies about deep-sea ecosystem services, the seabed mineral industry has always been discussed briefly and jointly with hydrocarbon resources. In the present study, we will discuss the deep-sea minerals separately, as there is an upsurge in interest in deep seabed mining, mainly due to the depletion of minerals from land sources and the fast growing demand for metals such as copper, cobalt and Rare Earth Elements that serve as raw material for high and green technology applications.

Since the signing of UNCLOS in 1982 and the establishment of the International Seabed Authority (ISA) in 1994, deep-sea mining exploration beyond national jurisdiction has been regulated under contracts managed by the ISA on behalf of its Member States. Currently, the ISA has granted 30 contracts to 21 contractors, sponsored by Member States, to explore the deep seabed, called the Area, which is considered the heritage of humankind. Three types of mineral deposits have commercial interest: polymetallic nodules (PN), seafloor massive sulfides (SMS) and cobalt-rich ferromanganese crusts (FeMn). The three deposits enclose valuable metals such as manganese, nickel, copper, cobalt (PN, [74]), Rare Earth Elements (FeMn, [75]) and lower levels of precious metals such as gold and silver (SMS, [76]). On average, the mineral deposits occur at depths greater than $800 \mathrm{~m}$. Eighteen contracts with the ISA are designed for the exploration of PN in the Clarion Clipperton Fracture Zone in the Equatorial Pacific (16), in the Western Pacific ocean (1) and in the Central Indian Ocean Basin (1). Seven contracts for the exploration of SMS are active in the Mid-Atlantic ridge, in the Central Indian Ridge and in the South-West Indian Ridge, and five contracts for the exploration of FeMn have been granted in the Western Pacific Ocean [77]. The allocated area for each contractor, after the relinquishment in favor of the ISA and developing countries, is $75,000 \mathrm{~km}^{2}$ for PN; $10,000 \mathrm{~km}^{2}$, consisting of 100 blocks not larger than $100 \mathrm{~km}^{2}$ each, for SMS; and $3000 \mathrm{~km}^{2}$ consisting of 50 blocks, not larger than $20 \mathrm{~km}^{2}$, for FeMn [77]. 
The commercial interest in these deposits has grown in the last decades, however, knowledge gaps on deep-sea ecosystems' functions [78], the potential environmental impacts of mining operations [79], uncertain economic risks as well as technological difficulties [80] remain the main challenges standing against the commercial viability of deep-sea mining [52,81,82].

\section{Marine Renewable Energy (MRE)}

The deep sea hosts a high potential to produce clean energy and reduce the carbon footprint. For this reason, marine renewable energy (MRE), and particularly offshore wind energy (OWE), has the support of both society and state policy [83]. This is particularly evident if compared with the onshore windmills, which received many negative opinions about the turbine engines, which are seen as unprofitable, inefficient, visually intrusive and noisy [84]. Thus, for all these reasons, currently, there is an increasing trend toward using marine renewable energy. Over the last decade, the OWE industry has changed its standards from fixed foundation turbines anchored at the seafloor for water depths above $60 \mathrm{~m}$ to floating turbines that can be moored in waters as deep as $1000 \mathrm{~m}[85,86]$. Furthermore, the most significant resource potential is believed to be in deep water with $230,004 \mathrm{TWh} /$ year at the global scale [87]. At the end of 2019, 65.7 MW of floating offshore wind capacity have been installed in Portugal, the UK, Norway, France and Japan, and the worldwide offshore wind industry touched 6.1 GW of new installations, making 2019 the first best year ever [88].

\section{Biotechnology and Chemical Compounds for Industrial and Pharmaceutical Uses}

The oceans have a vast genetic richness that offers commercial opportunities for biotechnology, agriculture and pharmaceutical industries [89]. The continuous discovery of deep-sea microorganisms is revealing surprising genetic diversity: eukaryotic species range between 700,000 and 1 million [90], and prokaryotic [91] and viral taxa [92] are represented by more than one million species. Deep seas cover more than $90 \%$ of the biosphere, and their high microbic diversity represents a potential source of wealth, profitmaking and commercial opportunities because some may be of interest for human well-being and environmental remediation [93].

The deep sea contains different habitats such as hydrothermal vents, deep-sea trenches, deep-water corals and cold seeps, which possess high biotechnological potential due to their large biological diversity and environmental adaptation to extreme conditions in terms of toxic chemical compounds [94]. However, these habitats are largely unknown; only $0.0001 \%$ (deepsea floor) to $10 \%$ (hydrothermal fields) of habitats are explored $[95,96]$, and they are certainly far less explored than shallow waters [97]. Technical difficulties, economic implications and sampling constraints at depths below $700 \mathrm{~m}$ [98] are most likely the cause of the current lack of research studies related to deep-sea biodiversity [95]. Thus, to date, the exact biotechnological potential of our oceans is still undiscovered, mainly in the deep sea.

\subsubsection{Regulating Services}

Gas and Climate Regulation

The "Biological Pump", which transports organic material (absorbed carbon during photosynthesis) from the ocean surface to the deep sea, is responsible for maintaining the chemical composition of the ocean and the atmosphere [99] and provides gas and climate regulation services. Marine microorganisms are at the core of the biological pump, by storing atmospheric $\mathrm{CO}_{2}$ produced by human activities [3]. Through this natural mechanism of carbon sequestration and storage, the deep sea provides climate regulation services [4] and releases nutrients that fuel production [11].

\section{Waste Absorption and Detoxification}

Deep seas provide an essential regulating service in waste absorption and detoxification through biotic and abiotic processes [4,11]. Marine organisms accumulate, transport, 
bury and transform pollutants (e.g., persistent organic pollutants, oil, micro- and macroplastics and sewage) through assimilation and direct or indirect chemical transformation, in a process called bioremediation, which is often facilitated by bioturbation [11].

Biological Regulation

Numerous pathogenic organisms are increasingly spreading over the globe [4], and deep-sea benthic organisms can provide a biological regulation and remove pests by ingesting or averting their outbreaks by competing for available resources. Therefore, deep-sea organisms tend to limit the development of pathogens in the ocean.

\subsubsection{Cultural Ecosystem Services}

Cultural ecosystem services design human cognitive and physical interactions with nature (e.g., landscape, seascape) $[100,101]$. These services are recognized to provide nonmaterial goods to human societies. The deep sea provides cultural ecosystem services that remain largely unexplored. These services include scientific research, aesthetic and inspirational services (entertainment, art, literature, tourism) and spiritual wealth.

\section{Scientific Research}

After the HMS Challenger expeditions in 1872-1876, the interest in breaching gaps regarding the ocean knowledge has progressed in parallel with technological advancement. Since then, research scientists have carried out many expeditions to explore the ocean, discover unknown species, describe them and understand the functions of deep-sea ecosystems.

Deep-sea sediment cores provide a global archive of paleoclimate and geochronology of anthropogenic perturbations [102], especially through the paleontological and geochemical study of fossils such as foraminifera and coccolithophores [103]. Deep-sea sediment cores provide a number of proxies (e.g., isotope chemistry, stratigraphy, sedimentary structures, ichnofacies, organic chemistry, paleoseismicity) that can trace the history of the oceans. Thus, deep-sea data and information enable the understanding of the past climate evolution and long-term dynamics of global cycles that can help predict and assess current and future climate and global changes and their effects on our planet and human well-being [4].

\section{Deep-Sea Cultural Heritage}

Deep-sea cultural heritage or underwater cultural heritage are integral parts of the human cultural heritage [101], e.g., shipwrecks provide valuable information about when (time) and how (natural disaster or human error) an accident occurred.

The importance of deep-sea cultural heritage led the Law of the Sea (UNCLOS Art. 49, Art. 303) to impose a duty on coastal countries to protect and preserve archeological sites. The development of human activities in the deep sea, including oil and gas extraction, bottom-trawling and MRE, put this cultural heritage at risk of damage [104]. In November 2011, UNESCO adopted a convention for protecting underwater cultural heritage and addressing threats from treasure hunting and human activities [105]. More recently, UNESCO has defined three sites with Outstanding Universal Value in the deep sea beyond national Jurisdiction (ABNJ). The three sites are the "Lost City Hydrothermal Field" in the Mid-Atlantic Ridge, the "Atlantis Bank" in the Indian Ocean and the "White Shark Café" located halfway between Hawaii and North America [106].

It is worth mentioning that deep-sea cultural services include habitats inaccessible to the large majority of the population and are therefore perceived as irrelevant and uninteresting [100]. However, cultural ecosystem services are meaningful and valuable to humans even without close interaction. As discussed in Garcia Rodrigues et al. [100], cultural ecosystem services such as inspiration and knowledge about deep-sea marine ecosystems through the tales of media [107], documentaries, exhibitions, books or even scientific publications can generate awareness about remote ecosystems in the general public and increase their cultural services $[10,108]$. 
Indigenous knowledge and perspectives about ecosystems and ecosystems services are also increasingly important [109], including transcendental values and communitybased management agreements [110].

\subsection{Combination Analysis of Deep-Sea Ecosystems Services}

\subsubsection{Fishing}

During the last four decades, the harvesting of deep-sea fisheries has increased due to the over-exploitation of continental shelf fish stocks $[64,111,112]$. Seabed fisheries deploying bottom fishing gear to catch the target species put the benthic environment at risk [113]. Numerous types of gear are used in deep-sea fisheries, such as bottom otter trawls, deep midwater trawls, bottom longlines, tangle nets, sink/anchor gillnets, pots and traps, which can destroy seabed habitats [114]. Recent studies on the ecological effects of bottomtrawling focused on the physical impacts on soft sediments [115,116], the destruction of submarine features [117] and the disturbance of benthic ecosystems, which concur to further decline the fish productivity [118].

Deep-sea species play an important role in biogeochemical cycling, which means that deep-sea fishery might affect the biogeochemistry of the global ocean. In addition, as previously said, deep-sea fishes are slow-growing (some fish live $>100$ years [119]), and it can take hundreds of years to recover a species once damaged. According to an expertbased evaluation, bottom-trawling represents the highest threat to the marine benthic habitat, and seamounts shallower than $2000 \mathrm{~m}$ are significantly vulnerable to this fishing technique [120]. Indeed, Ramalho et al. [121] reported that bottom-trawling has negatively influenced the benthic community and associated ecosystem functions in the Western Iberian continental margin. In the Aotearoa seamounts, offshore of New Zealand, over the few past years, scientists have discovered 128 new species from fisheries bycatch [122], and the New Zealand fleet's bottom nets dragged about 14.03 tons of corals in the 2018-2019 fishing year [123]. Many other studies pointed out the adverse indirect and direct effects of trawling on benthic invertebrate communities and populations worldwide, with marked declines in biomass, abundance, species diversity and productivity [124-130].

Not all bottom areas are open for fishing, especially in areas known as vulnerable marine ecosystems (VMEs). For example, around the Altair and Antialtair seamounts, which are listed as threatened habitat by the Convention for the Protection of the Marine Environment of the Northeast Atlantic [131], bottom-trawling is forbidden. In the Mediterranean Sea (North Africa and Europe) bottom-trawling was banned by the General Fisheries Commission for the Mediterranean in approximately 630,000 square miles of deep-sea waters. In the Pacific and Arctic Ocean and the Bering Sea, deep-sea bottomtrawling is prohibited by the Pacific and North Pacific Fishery Management Councils [132]. More recently, the European Parliament and the Council of the European Union have defined specific conditions for fishing deep-sea stocks in VMEs, where bottom gear for fishing is prohibited according to Article 9 (9) of Regulation (EU) 2016/2336. Similarly, new regulations were established to expand the deep-sea habitat protection in the U.S. West Coast from the impact of deep-sea trawling (Amendment 28). Globally, eight regional bodies have implemented competence over deep-sea fishing and adopted several measures to regulate fisheries. The regional commissions are spread into:

- The Northeast Atlantic Fisheries Commission (NEAFC);

- The Northwest Atlantic Fisheries Organisation (NAFO);

- The Southeast Atlantic Fisheries Organisation (SEAFO);

- The Southern Indian Ocean Fisheries Agreement (SIOFA);

- $\quad$ The North Pacific Fisheries Commission (NPFC);

- The General Fisheries Commission for the Mediterranean (GFCM);

- The South Pacific Regional Fisheries Management Organisation (SPRFMO);

- The Commission for the Conservation of Atlantic Marine Living Resources (CCAMLR).

Furthermore, bottom-trawling affects not only fish stocks and marine life components but also coastal tourism and local fishing communities because of overfishing as the gears 
are not selective and dispose of many dead fish [132]. Ocean-based tourism includes diving, snorkeling and sport fishing; these activities are directly threatened by the removal of marine wildlife that tourists most desire to see [132,133]. Furthermore, deep-sea fisheries are among the sources of marine litter (e.g., in the Arctic seafloor [134]).

However, the knowledge gap regarding the mesopelagic community and the lack of technologies allowing the exploration, sampling and observation of small organisms living at depths ranging from 200-1000 m opens the question about deep-sea fisheries economic and ecologic sustainability. In this respect, several projects (e.g., the MEESO project) are underway to study how to exploit mesopelagic fish sustainably and avoid damaging biodiversity and ecosystem services.

\subsubsection{Oil and Gas}

The depletion of gas and oil resources on land was among the factors leading to the exploration and exploitation of gas and oil in the deep sea, the so-called offshore oil and gas industry [135]. The operations consist of four stages: geological and geophysical investigation, exploration, production and decommissioning. Every step is associated with potential environmental impact, including chemical, physical and biological disturbance [136]. Due to the absence of sufficient data related to deep-sea ecosystems, the environmental impact assessment of such activities is still limited [137]. In addition, environmental management is challenging as deep-sea biological systems operate at a slower pace compared to shallow waters [138]. Anthropogenic stressors resulting from deep-water oil and gas operations in such fragile ecosystems may influence habitats and species, making re-colonization and recovery difficult $[139,140]$. Even in the absence of large environmental impacts, such as those caused by the incident at the Deepwater Horizon Macondo well [137], the exploration and extraction of oil and gas might affect life in deep-sea ecosystems, including species, assemblages and populations, or cause the modification of the ecological parameters of the ecosystem, productivity, biomass and biodiversity [69] (Table 1). For example, sound and light emitted during deep-water oil and gas operations cause disturbances in marine mammals' behaviors, including breeding, resting and feeding [141,142], while the impact of noise on fish and invertebrates is still poorly understood [143]. In addition, the acoustic disturbance resulting from the construction activities and offshore shipping impact ecosystems by affecting the physiology and behavior of benthic invertebrate species and bioturbating fauna in sediments [144]. Accidental oil spills can occur during the development and production stages at a high rate and sometimes in high volumes [137]. The large oil spill occurring in the Gulf of Mexico in 2010, known as the Macondo accident, has affected soft-bottom benthic communities [145], deep-sea corals [146] and caused a significant impact on the tourism and fisheries industries [137]. Although the long-term impacts of the Macondo accident remain poorly understood, as the insufficiency of pre-spill data made the full impact assessment limited [147], we can conclude that deep-water oil and gas operations can deteriorate species, habitats and alter biogeochemical and nutrient cycling (Table 1).

However, studies that have attempted to quantify the impacts of offshore operations on marine life agree to consider them low [148,149]. Bakke et al. [150] reviewed the environmental impact of operational discharges from offshore petroleum activities, including waste drilling and discharge water (e.g., habitat, biodiversity and fisheries stocks). They concluded that it is difficult to determine the effects of offshore oil and gas operations on deep-sea biodiversity and ecosystems, which thus remain largely unknown. On the contrary, the Great Amazon Reef System, comprised of mesophotic reefs at 70-220 m depth [151] built mainly by calcareous algae, is reported to face serious threats because of oil and gas exploration and exploitation [152].

Moreover, because cultural services, including coastal tourism, depend on healthy oceans and clean beaches, offshore oil and gas operations may potentially negatively impact the marine environment and influence the sustainability of tourism [153]. On the other hand, offshore oil and gas explorations open the door to the scientific research of deep-sea ecosystems and new technologies allow the exploitation of hydrocarbon without 
compromising other services. Therefore, the offshore oil and gas industry provides some services for human welfare but threatens others.

In summary, the lack of knowledge regarding deep-sea ecosystems, together with the few available studies related to the environmental impact assessment of deep-sea oil and gas operations, make uncertain the evaluation of the activity-related risks to supporting and provisioning services. Therefore, the precise impacts of deep-water oil and gas still need more assessment.

\subsubsection{Deep-Sea Minerals}

Deep-sea mineral extraction is identified as an alternative source of metals of economic interest and is claimed to be a future clean sector [154], unlike terrestrial mining, which generates pollutants into water and land [155]. On the other hand, the risk and sustainability of such activities is still undefined because the ecological aspects of the deep-sea are unknown and studies are very few [78]. The interest in this industry sector is substantially growing, but the risks associated with this kind of deep-sea operations remain immeasurable $[53,156]$. Commercial mining tests and scientific investigations on the disturbance of polymetallic nodules have shown that the impact is severe after dredging operations, especially on habitat and biodiversity [157-159], and restoration is far from being implemented [160]. The technologies and procedures for exploiting the deep sea for mining purposes could seriously harm the marine environment, including habitats, marine resources, biogeochemistry cycling and environmental quality and blue economy sectors (e.g., fisheries [161]). Even subtle changes in the morphology of deep-sea abyssal plains have the potential to cause severe changes in benthic habitats [162]. Furthermore, not only habitat and biodiversity in abyssal regions will be impacted by nodules operations, but the impact will also touch midwater and mesopelagic species together with biota through the entire water column, especially during the lifting of nodules to the surface [163]. Christiansen et al. [82] have reported that deep-sea mining operations will produce noise and sediment plumes, which may have significant ecological effects over the water column (sediment-water interface, midwater and surface water column) and the mid-water ecosystems would be especially affected [164]. According to Drazen et al. [164], deep-sea mining operations pose a substantial risk to services that provide midwater ecosystems, including biodiversity, habitat, biogeochemical cycling, nutrient regeneration and provisioning services (e.g., fish stocks).

Exploiting manganese nodules could significantly affect abyssal regions because their removal would delete specialized fauna living on the hard nodules such as sponges and other species living between soft sediment and nodules $[165,166]$. In addition, the sediment disturbance caused by the removal of manganese nodules and the discharged sediment plume, and its perturbations could decrease habitat complexity, ecosystem function and biodiversity [161]. The effects of mining polymetallic nodules are supposed to persist as the nodules are slow-growing and could take millions of years to grow, influencing biodiversity and habitat recovery [167].

Similarly to manganese nodules, the mining of SMS deposits would harm habitats, biogeochemical cycling and biodiversity $[168,169]$. Exceptional animal communities exist in SMS, which use to live and grow up under the extreme chemical conditions and high temperature around hydrothermal vents where SMS deposits form via the interaction between hot mineral-rich fluids and the surrounding cold water. Therefore, the extraction of SMS minerals would directly affect the biota $[167,170]$. To date, commercial extraction of SMS has been executed nowhere in the world except for leading-edge exploration in Japan [171]; thus, the nature and scale of the potential impacts of this activity are still unknown. Nevertheless, Orcutt et al. [2] have indicated that there would be impacts on biomass, microbial diversity and primary production at active vents, considering the unknown linkage between plume microbial communities and seafloor and sub-seafloor habitats [172]. On the other hand, at inactive SMS sites, the possible effects remain indistinguishable, as there is a knowledge gap concerning their ecology and the genetic and demographic link of populations between the different deposits [173]. 
Likewise, the extraction of FeMn is expected to heavily influence deep-sea ecosystem services such as biodiversity [82], biomass, microbial diversity and biogeochemical function [2]. FeMn serves as a hard bedrock for benthic organisms, such as sponges or substratum for the egg-laying of mobile species (e.g., octopus [174]). Thus, the exploitation of FeMn would impact both macro- and microfauna over the seamounts. The latter plays a crucial role in chemical cycling occurring in these habitats [11] and represents a vast and varied genetic reservoir of economic and commercial interest.

Attempts have been made to assess ecosystem services in the frame of deep-sea mineral mining, however, it was recognized that knowledge gaps prevent the full operationalization of ecosystem services concepts in the deep-seabed and that new technologies and findings, including next-generation genetic tools, biological traits analysis, innovative marine robotics, will be crucial in this regard [175].

We conclude that deep-sea ecosystems provide many services and play a crucial role in the global functioning of the earth planet, which is primarily dependent on deep-sea biodiversity. The exploitation of minerals from the deep sea will negatively influence these ecosystems at all levels (Table 1).

\subsubsection{Marine Renewable Energy (MRE)}

MRE, the so-called ocean-based energy, looks promising in tackling dioxide emissions, meeting the growing energy demand, and reducing the human contribution to global warming [176]. MRE include offshore winds farms (OWFs), solar energy, wave and tidal energy, in the latter case, the mattresses that stabilize submarine power cable may enhance benthic megafauna habitat capacity and increase artificial habitats for a range of fish and crustacean species [177]. On the contrary, Dannheim et al. [178] reported that MRE installations might impact the benthic compartment during the construction, operational or decommissioning stages.

The deep-sea OWE industry exerts potential associated risks and stressors on the environment that were defined by Boehlert and Gill [179] and Copping et al. [180]. These can be summarized as follows: (i) atmospheric and oceanic dynamics changes resulting from energy modification and removal; (ii) habitat alterations; (iii) electromagnetic field influence on deep-sea species from cables; (iv) underwater noise effects on marine species; (v) water quality changes.

As illustrated in Table 1, MRE can therefore present both negative and positive impacts on the seafloor, nutrient cycling and habitat at the construction phase. For example, some supporting services (e.g., habitat, nutrient cycle) change due to the reduction in habitat (soft sediment) at turbine bases, as a result of the introduction of a rigid substrate [181,182]. The piling activities, which are known to moderately influence the seafloor, can cause the relocation of certain fish species because of the emitted noise (Table 1) [182]. Unclear or no impact on primary production (PP) has been identified during the construction of OWFs, as the annual PP remains unaltered before and after the construction [183]. Regarding waste absorption and detoxification (biological remediation), the growth of bivalve populations around wind turbines can help improve the water quality [184]. In addition, the increase in algae, marine bacteria and crabs around OWFs may enhance heavy metal remediation [185].

Regarding the cultural services, MRE inspired scientific and technological research, governance and maintenance strategies and novel marine policies directly developed for marine renewable energy. In addition, increased commercial interest in offshore deep-water (60-1000 m) wind energy enhanced the environmental concern and the general awareness about deep-sea ecosystem services [79,186-188]. 
Table 1. Combination of provisioning services and other types of deep-sea ES. (Red: negative impact, Orange: Negative/positive impact, Green: positive impact).

\begin{tabular}{|c|c|c|c|c|c|c|c|c|c|c|c|c|c|}
\hline & & \multicolumn{4}{|c|}{ Supporting Services } & \multicolumn{3}{|c|}{ Regulating Services } & \multicolumn{3}{|c|}{ Cultural Services } & \multirow[b]{2}{*}{$\begin{array}{c}\text { Human } \\
\text { Well-Being }\end{array}$} & \multirow[b]{2}{*}{$\begin{array}{c}\text { Marine } \\
\text { Environment } \\
\text { Quality }\end{array}$} \\
\hline & & Habitat & $\begin{array}{l}\text { Nutrient } \\
\text { Cycling } \\
\text { Water } \\
\text { Cycling }\end{array}$ & $\begin{array}{c}\text { Chemosynthesis } \\
\text { Primary } \\
\text { Production }\end{array}$ & Resilience & $\begin{array}{l}\text { Climate } \\
\text { Regulation }\end{array}$ & $\begin{array}{l}\text { Biological } \\
\text { Regulation }\end{array}$ & $\begin{array}{l}\text { Waste } \\
\text { Absorption } \\
\text { and Detoxi- } \\
\text { fication }\end{array}$ & $\begin{array}{c}\text { Education, } \\
\text { Scientific } \\
\text { Research \& } \\
\text { Knowledge }\end{array}$ & $\begin{array}{l}\text { Cultural } \\
\text { Meaning }\end{array}$ & Tourism & & \\
\hline \multirow{4}{*}{ 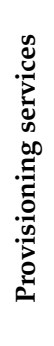 } & Fishing & - & - & - & - & $-/+$ & $-/+$ & $-/+$ & + & + & + & + & - \\
\hline & Oil and gas & - & - & - & - & - & - & - & + & - & - & - & - \\
\hline & MRE & $-/+$ & $-/+$ & $-1+$ & + & + & $-/+$ & + & + & + & $-/+$ & + & $-/+$ \\
\hline & Biotechnology & + & + & + & + & + & + & + & + & + & + & + & + \\
\hline
\end{tabular}


The tourism sector can be either positively or negatively impacted by OWFs, and therefore, a generalized cost-benefit analysis remains difficult to assess. For example, the construction of wind farms in a tourist destination in southern New England has increased the monthly revenues of Airbnbs there [189]. Conversely, a study conducted in the southern Baltic Sea has shown the negative impacts of OWFs on the tourism sector [190]. Another study performed in Scotland, based on tourists' responses, points out that they would not visit the area in the future because of wind farms, a survey that caused job loss [191].

\subsubsection{Biotechnology and Chemical Compounds for Industrial and Pharmaceutical Uses}

Chemicals from anthropogenic sources tend to harm the ocean and human health [192]. The increase of human activities around and in the ocean, including oil and gas exploitation, deep-sea mining operations, fishing, coastal tourism and shipping contribute largely to the accumulation of toxic chemicals in marine ecosystems such as heavy metals [193], persistent organic chemicals (POC) [194] and radioactive elements [195,196]. In many coastal areas around the world, the concentrations of toxic chemicals are extremely high. Therefore, new biotechnology approaches represent the fundamental solution for tackling the challenge of "human need growing" vs. "pressure on marine resources" and are an efficient tool for environmental bioremediation [197].

Regarding deep-sea biotechnology, the development of sampling and monitoring technology allowed the discovery of new microorganisms, genetic resource diversity and novel natural products of economic interest for environmental bioremediation [198]. Thus, deep-sea biotechnology as a provisioning service impacts positively other provided services (Table 1), including human well-being (e.g., drug discovery, industrial materials, biorefining, biofuels and bioenergy) [199] and marine environment conservation (e.g., monitoring and assessing environmental change, pollution prevention and ecosystem recovery and biodiversity conservation) [200,201].

\section{Conclusions}

In order to understand how human activities impact deep-sea ecosystems, ecology and functioning, it is first mandatory to review and quantify deep-sea ecosystem services and benefits and then evaluate how they may respond to the pressures and threats arising from the combined impacts of deep-sea resources exploitation and environmental changes.

Accordingly, this paper was designed to analyze deep-sea ecosystem services and investigate the potential impact of provisioning services, including deep-sea mining operations, fishing, biotechnology and marine renewable energies, on the other services and goods that these ecosystems provide.

Identifying the possible impacts of economic activities on deep-sea ecosystem services must integrate multidisciplinary approaches, which shall take into account the whole ecosystem's components (microorganisms, habitat, biogeochemical cycling, etc.). However, such assessment cannot be realized with a high degree of certainty and confidence since there is a lack of knowledge regarding deep-sea ecosystems, which is the biggest challenge facing the development and execution, for example, of mineral extraction and gene mining for biotechnological applications.

Despite the knowledge gap regarding deep-sea ecosystems' functions, properties and resources, the current understanding reveals the benefits that these ecosystems provide to the Earth and human beings and highlights the need for urgent conservation actions aimed at keeping the environment, economy and social components in balance.

Therefore, given the importance of deep-sea marine resources for human well-being, any activity launched in this complex ecosystem must take into account concurrent activities, the different uses of the sea and improvements in marine and maritime spatial planning. In addition, novel marine policies must be built based on multidisciplinary approaches as each service feeds back into the others to ensure the sustainable growth of the deep-sea economy. 
The present study may serve as a reference document about the envisaged environmental impacts of industries such as deep-sea mining and targets the industry and academic communities working in oceanography, environment, oil and gas industry, mineral mining, renewable energy industry, tourism and biotechnology.

Author Contributions: Conceptualization, N.M. and M.R.; methodology, N.M. and M.R.; software, N.M. and M.R.; validation, N.M. and M.R.; formal analysis, N.M. and M.R.; investigation, N.M. and M.R.; resources, N.M. and M.R.; data curation, N.M. and M.R.; writing-original draft preparation, N.M. and M.R.; writing-review and editing, N.M. and M.R.; visualization, N.M. and M.R.; supervision, M.R. All authors have read and agreed to the published version of the manuscript.

Funding: This research received no external funding.

Data Availability Statement: The data presented in this study are available upon request from the corresponding author.

Acknowledgments: This research work was carried within the framework of the DeepBlue Project (Developing Education and Employment Partnerships for a Sustainable Blue Growth in the Western Mediterranean) co-funded by the European Maritime and Fisheries Fund (EMFF). Nezha MEJJAD was supported by the Deep Blue Project during her mobility to the National Research Council—ISMAR Institute of Marine Sciences-CNR, Italy. Nezha MEJJAD would like to thank Valerio FUNARI for his valuable advice and support on the design of the literature search query. We would also like to highlight that this review paper has been made possible thanks to the Dimensions.ai database.

Conflicts of Interest: The authors declare no conflict of interest.

\section{References}

1. Gage, J.D.; Tyler, P.A. Deep-Sea Biology: A Natural History of Organisms at the Deep-Sea Floor; Cambridge University Press: Cambridge, MA, USA, 1991.

2. Orcutt, B.N.; Bradley, J.; Brazelton, W.J.; Estes, E.J.; Goordial, J.M.; Huber, J.A.; Jones, R.M.; Mahmoudi, N.; Marlow, J.J.; Murdock, S.; et al. Impacts of Deep-Sea Mining on Microbial Ecosystem Services. Limnol. Oceanogr. 2020, 65, 1489-1510. [CrossRef]

3. York, A. Marine biogeochemical cycles in a changing world. Nat. Rev. Microbiol. 2018, 16, 259. [CrossRef]

4. Armstrong, C.W.; Foley, N.S.; Tinch, R.; van den Hove, S. Services from the deep: Steps towards valuation of deep sea goods and services. Ecosyst. Serv. 2012, 2, 2-13. [CrossRef]

5. Koslow, A.J. The silent deep: The discovery, ecology, and conservation of the deep sea. Oceanography 2007, 23, 228.

6. Dell'Anno, A.; Danovaro, R. Extracellular DNA Plays a Key Role in Deep-Sea Ecosystem Functioning. Science 2005, $309,2179$. [CrossRef] [PubMed]

7. Danovaro, R.; Gambi, C.; Dell'Anno, A.; Corinaldesi, C.; Fraschetti, S.; Vanreusel, A.; Vincx, M.; Gooday, A.J. Exponential decline of deep-sea ecosystem functioning linked to benthic biodiversity loss. Curr. Biol. 2008, 18, 1-8. [CrossRef] [PubMed]

8. Llodra, E.R.; Billett, D.S.M. Deep-sea ecosystems: Pristine biodiversity reservoir and technological challenges. In The Exploration of Marine Biodiversity: Scientific and Technological Challenges; Duarte, C.M., Ed.; Fundación BBVA: Bilbao, Spain, 2006 ; pp. 63-92.

9. Asp, N.E.; Gomes, J.D.; Gomes, V.J.C.; Omachi, C.Y.; Silva, A.M.M.; Siegle, A.; Serrao, P.F.; Thompson, C.C.; Nogueira, L.C.; Francini-Filho, R.B.; et al. Water column and bottom gradients on the continental shelf eastward of the Amazon River mouth and implications for mesophotic reef occurrence. J. Mar. Syst. 2022, 225, 103642. [CrossRef]

10. Jobstvogt, N.; Townsend, M.; Witte, U.; Hanley, N. How Can We Identify and Communicate the Ecological Value of Deep-Sea Ecosystem Services? PLoS ONE 2014, 9, e100646. [CrossRef]

11. Thurber, A.R.; Sweetman, A.K.; Narayanaswamy, B.E.; Jones, D.O.B.; Ingels, J.; Hansman, R.L. Ecosystem function and services provided by the deep sea. Biogeosciences 2014, 11, 3941-3963. [CrossRef]

12. Townsend, M.; Davies, K.; Hanley, N.; Hewitt, J.E.; Lundquist, C.J.; Lohrer, A.M. The Challenge of Implementing the Marine Ecosystem Service Concept. Front. Mar. Sci. 2018, 5, 359. [CrossRef]

13. Barbier, E.B. Marine ecosystem services. Curr. Biol. 2017, 27, R507-R510. [CrossRef]

14. Velasco, A.M.; Pérez-Ruzafa, A.; Martínez-Paz, J.M.; Marcos, C. Ecosystem services and main environmental risks in a coastal lagoon (Mar Menor, Murcia, SE Spain): The public perception. J. Nat. Conserv. 2018, 43, 180-189. [CrossRef]

15. Newton, A.; Brito, A.C.; Icely, J.D.; Derolez, V.; Clara, I.; Angus, S.; Schernewski, G.; Inácio, M.; Lillebø, A.I.; Sousa, A.I.; et al. Assessing, quantifying and valuing the ecosystem services of coastal lagoons. J. Nat. Conserv. 2018, 44, 50-65. [CrossRef]

16. Aung, T.D.W.; Kyi, S.W.; Suzue, K.; Theint, S.M.; Tsujita, K.; Yu, T.T.; Merriman, J.C.; Peh, K.S.-H. Rapid ecosystem service assessment of a protected wetland in Myanmar, and implications for policy development and management. Ecosyst. Serv. 2021, 50, 101336. [CrossRef]

17. Sinclair, M.; Sagar, M.K.V.; Knudsen, C.; Sabu, J.; Ghermandi, A. Economic appraisal of ecosystem services and restoration scenarios in a tropical coastal Ramsar wetland in India. Ecosyst. Serv. 2021, 47, 101236. [CrossRef] 
18. Sagoe, A.A.; Aheto, D.W.; Okyere, I.; Adade, R.; Odoi, J. Community participation in assessment of fisheries-related ecosystem services towards the establishment of marine protected area in the Greater Cape Three Points area in Ghana. Mar. Policy 2021, 124, 104336. [CrossRef]

19. Mejjad, N.; Radouane, N.; Al Masmoudi, Y.; Saghrouchni, H. State and pressures on ecosystem services of agricultural land in the Mediterranean area. In Understanding the Current Status, Emerging Challenges, Global Uncertainties and Coping Mechanisms of Agriculture and Food Systems around the Mediterranean: Proceedings of the Mediterranean Forum for Ph.D. Students and Young Researchers, Online-CIHEAM, CIHEAM-Montpellier, Montpellier, France, 6-7 July 2021; Belhouchette, H., Ed.; CIHEAM: Montpellier, France, 2021; pp. 12-13.

20. Mayor, D.; Thornton, B.; Hay, S.; Zuur, A.F.; Nicol, G.W.; McWilliam, J.M.; Witte, U.F. Resource quality affects carbon cycling in deep-sea sediments. ISME J. 2012, 6, 1740-1748. [CrossRef] [PubMed]

21. Danovaro, R.; Fanelli, E.; Aguzzi, J.; Yasuhara, M. Ecological variables for developing a global deep-ocean monitoring and conservation strategy. Nat. Ecol. Evol. 2020, 4, 181-192. [CrossRef]

22. Tunnicliffe, V.; Juniper, K.S.; Sibuet, M. Reducing environments of the deep-sea floor. In Ecosystems of the World, 28 Ecosystems of the Deep Oceans; Tyler, P.A., Ed.; Elsevier: London, UK, 2003; pp. 81-110.

23. UNEP. Marine Litter: A Global Challenge; UNEP: Nairobi, Kenya, 2009.

24. Angiolillo, M. Debris in deep water. In World Seas: An Environmental Evaluation, 2nd ed.; Sheppard, C., Ed.; Academic Press: Cambridge, MA, USA, 2019; pp. 251-268.

25. Pham, C.; Ramirez-Llodra, E.; Alt, C.; Amaro, T.; Bergmann, M.; Canals, M.; Company, J.B.; Davies, J.; Tubau, X.; Van Rooij, D.; et al. Marine litter distribution and density in European Seas, from the shelves to deep basins. PLoS ONE 2014, 9, e95839. [CrossRef] [PubMed]

26. Pitcher, T.J.; Clark, M.R.; Morato, T.; Watson, R. Seamount Fisheries: Do They Have a Future? Oceanography 2010, $23,134-144$. [CrossRef]

27. Larsson, A.I.; Purser, A. Sedimentation on the cold-water coral Lophelia pertusa: Cleaning efficiency from natural sediments and drill cuttings. Mar. Poll. Bull. 2011, 62, 1159-1168. [CrossRef]

28. Martín-Martín, A.; Thelwall, M.; Orduna-Malea, E.; López-Cózar, E.D. Google Scholar, Microsoft Academic, Scopus, Dimensions, Web of Science, and OpenCitations' COCI: A multidisciplinary comparison of coverage via citations. Scientometrics 2021, 126, 871906. [CrossRef] [PubMed]

29. Herzog, C.; Hook, D.; Konkiel, S. Dimensions: Bringing down barriers between scientometricians and data. Quant. Sci. Stud. 2020, 1, 387-395. [CrossRef]

30. Hook, D.W.; Porter, S.J.; Herzog, C. Dimensions: Building context for search and evaluation. Front. Res. Metr. Anal. 2018, 3, 23. [CrossRef]

31. García-Sánchez, P.; Morab, A.M.; Castilloc, P.A.; Pérez, I.J. A bibliometric study of the research area of video games using Dimensions.ai database. In Proceedings of the 7th International Conference on Information Technology and Quantitative Management (ITQM2019), Granada, Spain, 5-6 November 2019; pp. 737-744.

32. Hook, D.; Porter, S.; Porter, S. How COVID-19 is changing research culture. Rep. Digit. Sci. 2020. [CrossRef]

33. Hook, W.D.; Porter, S.J.; Draux, H.; Herzog, C.T. Real-Time Bibliometrics: Dimensions as a Resource for Analyzing Aspects of COVID-19. Front. Res. Metr. Anal. 2021, 5, 595299. [CrossRef]

34. Khan, D.; Arjmandi, M.K.; Yuvaraj, M. Most Cited Works on Cloud Computing: The 'Citation Classics' as Viewed through Dimensions.ai. Sci. Tech. Libr. 2021. [CrossRef]

35. Jan van Eck, J.; Waltman, L. VOSviewer Manual. (Manual for VOSviewer Version 1.6.17); University Leiden: Lieden, The Netherlands, 2021.

36. Millenium Ecosystem Assessment. Ecosystems and Human Well-Being Synthesis Report; Island Press: Washington, DC, USA, 2005; p. 141.

37. TEEB. The Economics of Ecosystems and Biodiversity: Mainstreaming the Economics of Nature: A Synthesis of the Approach, Conclusions and Recommendations of TEEB; UNEP: Nairobi, Kenya, 2010; p. 29.

38. CICES. Common International Classification of Ecosystem Services; University of Nottingham: Notthingham, UK, 2013.

39. IPBES. Update on the Classification of Nature's Contributions to People by the Intergovernmental Science-Policy Platform on Biodiversity and Ecosystem Services; IPBES: Bonn, Germany, 2017.

40. Carpenter, K.E.; Abrar, M.; Aeby, G.; Aronson, R.B.; Banks, S.; Bruckner, A.; Chiriboga, A.; Cortés, J.; Weil, E.; Wood, E. One-Third of Reef-Building Corals Face Elevated Extinction Risk from Climate Change and Local Impacts. Science 2008, 321, $560-563$. [CrossRef] [PubMed]

41. Balmford, A.; Rodrigues, A.S.L.; Walpole, M.; Ten Brinck, P.; Kettunen, M.; Braat, L.; De Groot, R.S. The Economics of Ecosystems and Biodiversity: Scoping the Science; European Comission: Cambridge, UK, 2008; 305p.

42. Haines-Young, R.; Potschin, M. Common International Classification of Ecosystem Services (CICES): Consultation on Version 4; University of Nottingham: Nottingham, UK, 2009.

43. Apgar, J.M.; Cohen, P.J.; Ratner, B.D.; De Silva, S.; Buisson, M.-C.; Longley, C.; Bastakoti, R.; Mapedza, E. Identifying opportunities to improve governance of aquatic agricultural systems through participatory action research. Ecol. Soc. 2017, 22, 9. [CrossRef]

44. Mace, G.; Bateman, I.J.; Albon, S.; Balmford, A.; Church, A.; Winn, J. Conceptual Framework and Methodology, Report to the UK National Ecosystem Assessment; UNEP-WCMC: Cambridge, UK, 2009. 
45. Costa, C.; Fanelli, E.; Marini, S.; Danovaro, R.; Aguzzi, J. Global Deep-Sea Biodiversity Research Trends Highlighted by Science Mapping Approach. Front. Mar. Sci. 2020, 7, 384. [CrossRef]

46. Jalal, S.K. Co-authorship and co-occurrences analysis using BibliometrixR package: A case study of India and Bangladesh. Ann. Libr. Inf. Stud. 2019, 66, 57-64.

47. An, X.Y.; Wu, Q.Q. Co-word analysis of the trends in stem cells field based on subject heading weighting. Scientometrics 2011, 88, 133-144. [CrossRef]

48. Hu, J.; Zhang, Y. Research patterns and trends of Recommendation System in China using co-word analysis. Inf. Process. Manag. 2015, 51, 329-339. [CrossRef]

49. Chen, X.; Chen, J.; Wu, D.; Xie, Y.; Li, J. Mapping the research trends by co-word analysis based on keywords from funded project. Procedia Comput. Sci. 2016, 91, 547-555. [CrossRef]

50. Sharma, R. Deep-Sea Mining: Resource Potential, Technical and Environmental Considerations; Springer: Amsterdam, The Netherlands, 2017; 535p.

51. Lusty, P.A.J.; Murton, B.J. Deep-Ocean Mineral Deposits: Metal Resources and Windows into Earth Processes. Elements 2018, 14, 301-306. [CrossRef]

52. Miller, K.A.; Thompson, K.F.; Johnston, P.; Santillo, D. An overview of seabed mining including the current state of development, environmental impacts, and knowledge gaps. Front. Mar. Sci. 2018, 4, 418. [CrossRef]

53. Roux, S.; Horsfield, C. Chapter 13 Review of National Legislations Applicable to Seabed Mineral Resources Exploitation. In The Law of the Seabed; Brill I Nijhoff: Lieden, The Netherlands, 2020.

54. Levin, L.A.; Sibuet, M. Understanding continental margin biodiversity: A new imperative. Annu. Rev. Mar. Sci. 2012, 4, 79-112. [CrossRef]

55. Aguzzi, J.; Chatzievangelou, D.; Marini, S.; Fanelli, E.; Roberto Danovaro, R.; Flögel, S.; Company, J.B. New High-Tech Flexible Networks for the Monitoring of Deep-Sea Ecosystems. Environ. Sci. Technol. 2019, 53, 6616-6631. [CrossRef]

56. Valentine, J.W.; Jablonski, D. A twofold role for global energy gradients in marine biodiversity trends. J. Biogeogr. 2015, 42, 997-1005. [CrossRef]

57. Eyal, G.; Pinheiro, H.T. Mesophotic Ecosystems: The Link between Shallow and Deep-Sea Habitats. Diversity 2020, $12,411$. [CrossRef]

58. Costanza, R.; D'Arge, R.; De Groot, R.; Farber, S.; Grasso, M.; Hannon, B.; Limburg, K.; Van Den Belt, M. The value of the world's ecosystem services and natural capital. Nature 1997, 387, 253-260. [CrossRef]

59. United Nations Environment Programme (UNEP). Deep-Sea Biodiversity and Ecosystems: A Scoping Report on Their SocioEconomy, Managementand Governance. 2007. Available online: https://www.unep-wcmc.org/resources-and-data/deep-seabiodiversity-and-ecosystems (accessed on 28 May 2021).

60. Cochonat, P.; Durr, S.; Gunn, V.; Herzig, P.; Mevel, C.; Mienert, J.; Schneider, R.; Weaver, P.; Winkler, A. The Deep-Sea Frontier: Science Challenges for a Sustainable Future; Office for Official Publications of the European Communities: Luxembourg, 2007 ; p. 53.

61. Jørgensen, B.B.; Boetius, A. Feast and famine-Microbial life in the deep-sea bed. Nat. Rev. Microbiol. 2007, 5, 770-781. [CrossRef]

62. Levin, L.A. Oxygen minimum zone benthos: Adaptation and community response to hypoxia. Oceanogr. Mar. Biol. 2003, 41, 1-45.

63. Sibuet, M.; Roy, K.O.L. Cold Seep Communities on Continental Margins: Structure and Quantitative Distribution Relative to Geological and Fluid Venting Patterns. In Ocean. Margin Systems; Wefer, G., Billett, D., Hebbeln, D., Jørgensen, B.B., Schlüter, M., van Weering, T.C.E., Eds.; Springer: Berlin/Heidelberg, Germany, 2002.

64. Levin, L.A.; Liu, K.-K.; Emeis, K.-C.; Breitburg, D.L.; Cloern, J.; Deutsch, C.; Giani, M.; Wishner, K. Comparative biogeochemistryecosystem-human interactions on dynamic continental margins. J. Mar. Syst. 2015, 141, 3-17. [CrossRef]

65. Gordon, J.D.M. Deep-water fisheries at the Atlantic Frontier. Cont. Shelf Res. 2001, 21, 987-1003. [CrossRef]

66. Roberts, J.M.; Wheeler, A.J.; Freiwald, A. Reefs of the deep: The biology and geology of cold-water coral ecosystems. Science 2006, 312, 543-547. [CrossRef]

67. Morato, T.; Watson, R.; Pitcher, T.J.; Pauly, D. Fishing down the deep. Fish Fish. 2006, 7, 24-34. [CrossRef]

68. Clark, M. Are deepwater fisheries sustainable? The example of orange roughy (Hoplostethus atlanticus) in New Zealand. Fish. Res. 2001, 51, 123-135. [CrossRef]

69. Cordes, E.E.; Jones, D.O.B.; Schlacher, T.A.; Amon, D.J.; Bernardino, A.F.; Brooke, S.; Carney, R.; DeLeo, D.M.; Dunlop, K.M.; Escobar-Briones, E.G.; et al. Environmental Impacts of the Deep-Water Oil and Gas Industry: A Review to Guide Management Strategies. Front. Environ. Sci. 2016, 4, 58. [CrossRef]

70. Zhang, G.; Qu, H.; Chen, G.; Zhao, C.; Zhang, F.; Yang, H.; Zhao, Z.; Ma, M. Giant discoveries of oil and gas fields in global deepwaters in the past 40 years and the prospect of exploration. J. Nat. Gas Geosci. 2019, 4, 1-28. [CrossRef]

71. Cox, A. Subsidies and deep-sea fisheries management: Policy issues and challenges. OECD, Fisheries Division. In Proceedings of the Deep Sea 2003: Conference on the Governance and Management of Deep-sea Fisheries. Part. 1: Conference Reports, Queenstown, WA, New Zealand, 1-5 December 2003.

72. Sumaila, U.R.; Khan, A.S.; Dyck, A.J.; Watson, R.; Munro, G.; Tyedmers, P.; Pauly, D. A bottom-up re-estimation of global fisheries subsidies. J. Bioeconomics 2010, 12, 201-225. [CrossRef]

73. Beaubouef, B. Total wildcat off Angola to establish new water depth record. Offshore Mag. 2020. Available online: https://www. offshore-mag.com/drilling-completion/article/14168421/total-wildcat-off-angola-to-establish-new-water-depth-record (accessed on 4 July 2021). 
74. Hein, J.R.; Koschinsky, A.; Kuhn, T. Deep-ocean polymetallic nodules as a resource for critical materials. Nat. Rev. Earth Environ. 2020, 1, 158-169. [CrossRef]

75. Halbach, P.E.; Jahn, A.; Cherkashov, G. Marine Co-Rich Ferromanganese Crust Deposits: Description and Formation, Occurrences and Distribution, Estimated World-wide Resources. In Deep-Sea Mining; Springer: Lieden, The Netherlands, 2017.

76. Petersen, S.; Hein, J.R. The Geology of Sea-Floor Massive Sulphides. In Deep Sea Minerals: Sea-Floor Massive Sulphides, a Physical, Biological, Environmental, and Technical Review; Baker, E., Beaudoin, Y., Eds.; Secretariat of the Pacific Community: Noumea, New Caledonia, France, 2013.

77. International Seabed Authority (ISA). 2020. Available online: https:/ /isa.org.jm/ exploration-contracts (accessed on 15 March 2021).

78. Levin, L.A.; Amon, D.J.; Lily, H. Challenges to the sustainability of deep-seabed mining. Nat. Sustain. 2020, 3, 784-794. [CrossRef]

79. Van Dover, C.L.; Arnaud-Haond, S.; Gianni, M.; Helmreich, S.; Huber, J.A.; Jaeckel, A.L.; Yamamoto, H. Scientific Rationale and International Obligations for Protection of Active Hydrothermal Vent Ecosystems from Deep-Sea Mining. Mar. Policy 2018, 90, 20-28. [CrossRef]

80. Gerber, L.J.; Grogan, R.L. Challenges of operationalising good industry practice and best environmental practice in deep seabed mining regulation. Mar. Policy 2020, 114, 103257. [CrossRef]

81. Rovere, M. The Common Heritage applied to the resources of the seabed. Lessons learnt from the exploration of deep sea minerals and comparison to marine genetic resources. Mar. Saf. Law. J. 2018, 5, 78-98.

82. Christiansen, B.; Denda, A.; Christiansen, S. Potential effects of deep seabed mining on pelagic and benthopelagic biota. Mar. Policy 2020, 114, 103442. [CrossRef]

83. Zountouridou, E.I.; Kiokes, G.C.; Chakalis, S.; Georgilakis, P.S.; Hatziargyriou, N.D. Offshore floating wind parks in the deep waters of Mediterranean Sea. Renew. Sustain. Energy Rev. 2015, 51, 433-448. [CrossRef]

84. Bonar, P.; Bryden, I.; Borthwick, A. Social and ecological impacts of marine energy development. Renew. Sustain. Energy Rev. 2015, 47, 486-495. [CrossRef]

85. Loomis, R.; Kershaw, F. Floating Offshore Wind Brings Challenges and Opportunities. NRDC. 2021. Available online: https:// www.nrdc.org/experts/rebecca-loomis/floating-offshore-wind-brings-challenges-and-opportunities (accessed on 1 July 2021).

86. Pham, T.-D.; Dinh, M.-C.; Kim, H.-M.; Nguyen, T.-T. Simplified Floating Wind Turbine for Real-Time Modeling of Large-Scale Floating Offshore Wind Farms. Energies 2021, 14, 4571. [CrossRef]

87. Bosch, J.; Staffell, I.; Hawkes, A.D. Temporally explicit and spatially resolved global offshore wind energy potentials. Energy 2018, 163, 766-781. [CrossRef]

88. Council, G.W.E. GWEC I Global Wind Report 2021; Global Wind Energy Council: Brussels, Belgium, 2017.

89. Munro, M.H.G.; Blunt, J.W.; Dumdei, E.J.; Hickford, S.J.H.; Lilla, R.E.; Li, S.; Battershill, C.N.; Duckworth, A.R. The discovery and development of marine compounds with pharmaceutical potential. J. Biotechnol. 1999, 70, 15-25. [CrossRef]

90. Appeltans, W.; Ahyong, S.T.; Anderson, G.; Angel, M.V.; Artois, T.; Bailly, N.; Bamber, R.; Barber, A.; Bartsch, I.; Berta, A.; et al. The magnitude of global marine species diversity. Curr. Biol. 2012, 22, 2189-2202. [CrossRef] [PubMed]

91. Curtis, T.P.; Sloan, W.T.; Scannell, J.W. Estimating prokaryotic diversity and its limits. Proc. Natl. Acad. Sci. USA 2002, 99, 10494-10499. [CrossRef]

92. Suttle, C.A. Viruses: Unlocking the greatest biodiversity on Earth. Genome 2013, 56, 542-544. [CrossRef]

93. Beaumont, N.; Tinch, R. Goods and Services Related to the Marine Benthic Environment; Centre for Social and Economic Research on the Global Environment: Norwich, UK, 2003; pp. 3-14.

94. Baker, E.T.; Cormier, M.H.; Langmuir, C.H.; Zavala, K. Hydrothermal plumes along segments of contrasting magmatic influence, $15^{\circ} 20^{\prime}-18^{\circ} 30^{\prime}$ N, East Pacific Rise: Influence of axial faulting. Geochem. Geophys. Geosystems 2001, 2. [CrossRef]

95. Ramirez-Llodra, E.; Brandt, A.; Danovaro, R.; Mol, B.; Escobar, E.; German, C.; Vecchione, M. Deep, diverse and definitely different: Unique attributes of the world's largest ecosystem. Biogeosciences 2010, 7, 2851-2899. [CrossRef]

96. Beaulieu, S.E.; Graedel, T.E.; Hannington, M.D. Should we mine the deep seafloor? Earth's Future 2017, 5, 655-658. [CrossRef]

97. Aylward, F.O.; Eppley, J.M.; Smith, J.M.; Chavez, F.P.; Scholin, C.A.; DeLong, E.F. Expression networks in disparate marine habitats. Proc. Natl. Acad. Sci. USA 2015, 112, 5443-5448. [CrossRef]

98. Kennedy, J.; Flemer, B.; Jackson, S.A.; Morrissey, J.P.; O'Gara, F.; Dobson, A.D. Evidence of a putative deep sea specific microbiome in marine sponges. PLoS ONE 2014, 9, e91092. [CrossRef] [PubMed]

99. Schubert, W.; Bonnekoh, B.; Pommer, A.J.; Philipsen, L.; Böckelmann, R.; Malykh, Y.; Gollnick, H.; Friedenberger, M.; Bode, M.; Dress, A.W. Analyzing proteome topology and function by automated multidimensional fluorescence microscopy. Nat. Biotechnol. 2006, 24, 1270-1278. [CrossRef] [PubMed]

100. Garcia Rodrigues, J.; Conides, A.; Rivero Rodriguez, S.; Raicevich, S.; Pita, P.; Kleisner, K.; Pita, C.; Lopes, P.; Alonso Roldán, V.; Ramos, S.; et al. Marine and Coastal Cultural Ecosystem Services: Knowledge gaps and research priorities. One Ecosyst. 2017, 2, e12290. [CrossRef]

101. Ottaviani, D. Economic Value of Ecosystem Services from the Deep Seas and the Areas Beyond National Jurisdiction; Food \& Agriculture Org.: Rome, Italy, 2020.

102. Nellemann, C.; Hain, S.; Alder, J.E. In Dead Water-Merging of Climate Change with Pollution, Over-Harvest and Infestations in the World's Fishing Grounds, United Nations Environment Programme; GRID: Arendal, Norway, 2008.

103. Labeyrie, L.D.; Duplessy, J.C.; Blanc, P.L. Variations in mode of formation and temperature of oceanic deep waters over the past 125,000 years. Nature 1987, 327, 477-482. [CrossRef] 
104. Varmer, O. Underwater Cultural Heritage Law Study; U.S. Dept. of the Interior, Bureau of Ocean Energy Management: Herndon, VA, USA, 2014.

105. UNESCO. Convention on the Protection of the Underwater Cultural Heritage. 2 November 2001. Available online: http://www. unesco.org/new/en/culture/themes/underwater-cultural-heritage/2001-convention/official-text (accessed on 3 October 2021).

106. Freestone, D.; Laffoley, D.; Douvere, F.; Badman, T. World Heritage in the High Seas: An Idea Whose Time Has Come, World Heritage Reports; UNESCO: Paris, France, 2016; 92p.

107. Coscieme, L. Cultural ecosystem services: The inspirational value of ecosystems in popular music. Ecosyst. Serv. 2015, 16, 121-124. [CrossRef]

108. Börger, T.; Hattam, C.; Burdon, D.; Atkins, J.; Austen, M. Valuing conservation benefits of an offshore marine protected area. Ecol. Econ. 2014, 108, 229-241. [CrossRef]

109. Harmsworth, G.R.; Awatere, S. Indigenous Māori Knowledge and Perspectives of Ecosystems. In Ecosystem Services in New Zealand-Conditions and Trends; Manaaki Whenua Press: Manaaki Whenua, New Zealand, 2013; pp. $274-286$.

110. Ratana, K.; Williams, E.; Roper, D. Indigenous Values and Marine Ecosystem Management, A Literature Review; Prepared for Landcare Research; NIWA Client Report No: 2017046HN; Landcare Research: Hamilton, New Zealand, 2017.

111. Watson, R.A.; Morato, T. Fishing down the deep: Accounting for within-species changes in depth of fishing. Fish. Res. 2013, 140, 63-65. [CrossRef]

112. Pusceddu, A.; Bianchelli, S.; Martín, J.; Puig, P.; Palanques, A.; Masque, P.; Danovaro, R. Chronic and intensive bottom trawling impairs deep-sea biodiversity and ecosystem functioning. Proc. Natl. Acad. Sci. USA 2014, 111, 8861-8866. [CrossRef]

113. Kaiser, M.J.; Hilborn, R.; Jennings, S.; Amaroso, R.; Andersen, M.; Balliet, K.; Sutherland, W.J. Prioritization of knowledge-needs to achieve best practices for bottom trawling in relation to seabed habitats. Fish Fish. 2016, 17, 637-663. [CrossRef]

114. Clark, M.R.; Koslow, J.A. Impacts of Fisheries on Seamounts. In Seamounts: Ecology, Fisheries E Conservation; Pitcher, T.J., Morato, T., Hart, P.J.B., Clark, M.R., Haggan, N., Santos, R.S., Eds.; Wiley: Hoboken, NJ, USA, 2007; pp. 413-441.

115. O'Neill, F.G.; Ivanović, A. The Physical Impact of Towed Demersal Fishing Gears on Soft Sediments. 73 (Supplement). ICES J. Mar. Sci. 2016, 73 Suppl_1, i5-i14.

116. Bradshaw, C.; Jakobsson, M.; Brüchert, V.; Bonaglia, S.; Mörth, C.-M.; Muchowski, J.; Stranne, C.; Sköld, M. Physical Disturbance by Bottom Trawling Suspends Particulate Matter and Alters Biogeochemical Processes on and Near the Seafloor. Front. Mar. Sci. 2021, 8, 683331. [CrossRef]

117. Clark, M.R.; Althaus, F.; Schlacher, T.A.; Williams, A.; Bowden, D.A.; Rowden, A.A. The impacts of deep-sea fisheries on benthic communities: A review. ICES J. Mar. Sci. 2016, 73 (Suppl. 1), i51-i69. [CrossRef]

118. Collie, J.; Hiddink, J.G.; van Kooten, T.; Rijnsdorp, A.D.; Kaiser, M.J.; Jennings, S.; Hilborn, R. Indirect effects of bottom fishing on the productivity of marine fish. Fish Fish. 2017, 18, 619-637. [CrossRef]

119. Cailliet, G.M.; Andrews, A.H.; Burton, E.J.; Watters, D.L.; Kline, D.E.; Ferry-Graham, L.A. Age determination and validation studies of marine fishes: Do deep-dwellers live longer? Exp. Gerontol. 2001, 36, 739-764. [CrossRef]

120. MacDiarmid, A.; McKenzie, A.; Sturman, J.; Beaumont, J.; Mikaloff-Fletcher, S.; Dunne, J. Assessment of anthropogenic threats to New Zealand marine habitats. N. Z. Aquat. Environ. Biodivers. Rep. 2012, 93, 255.

121. Ramalho, S.P.; Lins, L.; Soetaert, K.; Lampadariou, N.; Cunha, M.R.; Vanreusel, A.; Pape, E. Ecosystem Functioning Under the Influence of Bottom-Trawling Disturbance: An Experimental Approach and Field Observations from a Continental Slope Area in the West Iberian Margin. Front. Mar. Sci. 2020, 7, 457. [CrossRef]

122. Schnabel, K.E.; Mills, V.S.; Tracey, D.M.; Macpherson, D.; Kelly, M.; Peart, R.A.; Maggs, J.Q.; Yeoman, J.; Wood, C.R. Identification of Benthic Invertebrate Samples from Research Trawls and Observer Trips 2020-2021. Available online: https://fs.fish.govt.nz (accessed on 12 August 2021).

123. Pitcher, R.; Williams, A.; Georgeson, L. Progress with Investigating Uncertainty in the Habitat Suitability Model Predictions and VME Indicator Taxa Thresholds Underpinning CMM 03-2019. Paper for SPRFMO SC7, SC7-DW21_rev. Available online: https: / / www.sprfmo.int/assets /2019-SC7 / Meeting-Docs/SC7-DW21-rev1-Uncertainty-in-model-predictions-and-VMEthresholds-for-CMM-03-2019.pdf (accessed on 20 July 2021).

124. Collie, J.S.; Hall, S.J.; Kaiser, M.J.; Poiner, I.R. A quantitative analysis of fishing impacts on shelf-sea benthos. J. Anim. Ecol. 2000, 69, 785-798. [CrossRef]

125. McConnaughey, R.A.; Syrjala, S.E.; Dew, C.B. Effects of chronic bottom trawling on the size structure of soft-bottom benthic invertebrates. In Benthic Habitats and the Effects of Fishing, Symposium; Barnes, P.W., Thomas, J.P., Eds.; American Fisheries Society: Bethesda, MD, USA, 2005; Volume 41, pp. 425-437.

126. Kaiser, M.J.; Clarke, K.R.; Hinz, H.; Austen, M.C.V.; Somerfield, P.J.; Karakassis, I. Global analysis of response and recovery of benthic biota to fishing. Mar. Ecol. Prog. Ser. 2006, 311, 1-14. [CrossRef]

127. Hiddink, J.G.; Jennings, S.; Sciberras, M.; Szostek, C.L.; Hughes, K.M.; Ellis, N.; Kaiser, M.J. Global analysis of depletion and recovery of seabed biota after bottom trawling disturbance. Proc. Natl. Acad. Sci. USA 2017, 114, 8301-8306. [CrossRef]

128. Sciberras, M.; Hiddink, J.G.; Jennings, S.; Szostek, C.L.; Hughes, K.M.; Kneafsey, B.; Kaiser, M.J. Response of benthic fauna to experimental bottom fishing: A global meta-analysis. Fish Fish. 2018, 19, 698-715. [CrossRef]

129. McConnaughey, R.A.; Hiddink, J.G.; Jennings, S.; Pitcher, C.R.; Kaiser, M.J.; Suuronen, P.; Hilborn, R. Choosing best practices for managing impacts of trawl fishing on seabed habitats and biota. Fish Fish. 2020, 21, 319-337. [CrossRef] 
130. Mazor, T.; Pitcher, C.R.; Rochester, W.; Kaiser, M.J.; Hiddink, J.G.; Jennings, S.; Hilborn, R. Trawl fishing impacts on the status of seabed fauna in diverse regions of the globe. Fish Fish. 2021, 22, 72-86. [CrossRef]

131. OSPAR. Commission Initial OSPAR List of Threatened and/or Declining Species and Habitats; OSPAR: London, UK, 2003; ISBN 1-904426-12-3.

132. Stiles, M.L.; Stockbridge, J.; Lande, M.; Hirshfield, M.F. Impacts of Bottom Trawlingon Fisheries, Tourism, and the Marine Environment. Ocean 2010. Available online: https:/ / oceana.org/sites/default/files/reports/Trawling_BZ_10may10_toAudrey. pdf (accessed on 15 September 2021).

133. Stiles, M.; Ylitalo-Ward, H.; Faure, P.; Hirshfield, M. There's no place like home: Deep seafloorecosystems of New England and the Mid-Atlantic. Oceana 2007. Available online: https:/ / oceana.org/reports/there $\%$ E2\%80\%99s-no-place-home-deep-seafloorecosystems-new-england-and-mid-atlantic (accessed on 15 September 2021).

134. Tekman, M.B.; Krumpen, T.; Bergmann, M. Marine litter on the Arctic seafloor continues to increase and spreads to the North at the HAUSGARTEN observatory. Deep Sea Res. I 2017, 120, 88-99. [CrossRef]

135. United Nations Environment Programme (UNEP). Wealth In the Oceans: Deep Sea Mining on The Horizon? Unep 2014, Global Environmental Alert Service (Geas). Available online: https:/ / wedocs.unep.org/handle/20.500.11822/8903 (accessed on 16 June 2021).

136. Patin, S. Environmental Impact of the Offshore Oil and Gas Industry; EcoMonitor: East Northport, NY, USA, 1999 ; pp. 53-54.

137. Vinogradov, S. The impact of the deepwater horizon: The evolving international legal regime for offshore accidental pollution prevention, preparedness, and response. Ocean Dev. Int. Law 2013, 44, 335-362. [CrossRef]

138. Smith, C.R. Tempo and mode in deep-sea benthic ecology: Punctuated equilibrium revisited. Palaios 1994, 9, 3-13. [CrossRef]

139. Grassle, J.F. Slow recolonisation of deep-sea sediment. Nature 1977, 265, 618-619. [CrossRef]

140. McClain, C.R.; Schlacher, T.A. On some hypotheses of diversity of animal life at great depths on the sea floor. Mar. Ecol. 2015, 36, 849-872. [CrossRef]

141. Southall, B.L.; Bowles, A.E.; Ellison, W.T.; Finneran, J.J.; Gentry, R.L.; Greene, C.R., Jr.; Tyack, P.L. Marine mammal noise exposure criteria: Initial scientific recommendations. Bioacoustics 2008, 17, 273-275. [CrossRef]

142. Moore, S.E.; Reeves, R.R.; Southall, B.L.; Ragen, T.J.; Suydam, R.S.; Clark, C.W. A new framework for assessing the effects of anthropogenic sound on marine mammals in a rapidly changing arctic. Bioscience 2012, 62, 289-295. [CrossRef]

143. Hawkins, A.D.; Pembroke, A.E.; Popper, A.N. Information gaps in understanding the effects of noise on fishes and invertebrates. Rev. Fish Biol. Fish. 2014, 25, 39-64. [CrossRef]

144. Solan, M.; Hauton, C.; Godbold, J.A.; Wood, C.L.; Leighton, T.G.; White, P. Anthropogenic sources of underwater sound can modify how sediment-dwelling invertebrates mediate ecosystem properties. Sci. Rep. 2016, 6, 20540. [CrossRef]

145. Montagna, P.A.; Baguley, J.G.; Cooksey, C.; Hartwell, I.; Hyde, L.J.; Hyland, J.L.; Rhodes, A.C. Deep-sea benthic footprint of the Deepwater Horizon blowout. PLoS ONE 2013, 8, e70540. [CrossRef] [PubMed]

146. White, H.K.; Hsing, P.-Y.; Cho, W.; Shank, T.M.; Cordes, E.E.; Quattrini, A.M.; Fisher, C.R. Impact of the Deepwater Horizon oil spill on a deep-water coral community in the Gulf of Mexico. Proc. Natl. Acad. Sci. USA 2012, 109, 20303-20308. [CrossRef]

147. Levin, L.A.; Bett, B.J.; Gates, A.R.; Heimbach, P.; Howe, B.M.; Janssen, F.; McCurdy, A.; Ruhl, H.A.; Snelgrove, P.; Weller, R.A. Global Observing Needs in the Deep Ocean. Front. Mar. Sci. 2019, 6, 241. [CrossRef]

148. Bjørgesæter, A. Environmental Effects of Oil and Gas Exploration on the Benthic Fauna of the Norwegian Continental Shelf: An Analysis Using the OLF-Database. Ph.D. Thesis, University of Oslo, Oslo, Norway, 2009. Available online: http:/ / urn.nb.no/URN: NBN:no-23919 (accessed on 26 August 2021).

149. Geutebruck, E.; Herler, J.; Kikinger, R.; Stachowitsch, M.; Lorkin, M. Environmental Impact of Offshore Oil and Gas Company Operations in the Southern Arabian Gulf: A Marine Environmental Survey. In Proceedings of the SPE International Conference on Health, Safety and Environment in Oil and Gas Exploration and Production, Kuala Lumpur, Malaysia, 20-22 March 2002.

150. Bakke, T.; Klungsøyr, J.; Sanni, S. Environmental impacts of produced water and drilling waste discharges from the Norwegian offshore petroleum industry. Mar. Environ. Res. 2013, 92, e154-e169. [CrossRef]

151. Moura, R.L.; Amado-Filho, G.M.; Moraes, F.C.; Brasileiro, P.S.; Salomon, P.S.; Mahiques, M.M.; Bastos, A.C.; Almeida, N.G.; Silva, J.M.; Araujo, B.F.; et al. An extensive reef system at the Amazon River mouth. Sci. Adv. 2016, 2, e1501252. [CrossRef]

152. Francini-Filho, R.B.; Coni, E.O.; Meirelles, P.M.; Amado-Filho, G.M.; Thompson, F.L.; Pereira-Filho, G.H.; Bastos, A.C.; Abrantes, D.P.; Ferreira, C.M.; Gibran, F.Z.; et al. Dynamics of coral reef benthic assemblages of the Abrolhos Bank, eastern Brazil: Inferences on natural and anthropogenic drivers. PLoS ONE 2013, 8, e54260. [CrossRef]

153. Waló, Á.N. Economic impacts of oil spills in island tourism destinations. An application to the Canary Islands. Memoria Del Trabajo Fin De Grado. In Economic Facultad De Economía, Empresa Y Turismo; Universidad de la Laguna: La Laguna, Spain, 2016; pp. 1-27.

154. Paulikas, D.; Katona, S.; Ilves, E.; Ali, S.H. Life cycle climate change impacts of producing battery metals from land ores versus deep-sea polymetallic nodules. J. Clean. Prod. 2020, 275, 123822. [CrossRef]

155. Beaulieu, S.E.; Baker, E.T.; German, C.R. Where are the undiscovered hydrothermal vents on oceanic spreading ridges? Deep Sea Res. Part II Top. Stud. Oceanogr. 2015, 121, 202-212. [CrossRef]

156. Halfar, J.; Fujita, R.M. Danger of Deep-Sea Mining. Sci. Policy Forum 2007, 316, 987.

157. Gollner, S.; Kaiser, S.; Menzel, L.; Jones, D.O.B.; Brown, A.; Mestre, N.C.; Martinez Arbizu, P. Resilience of benthic deep-sea fauna to mining activities. Mar. Environ. Res. 2017, 29, 76-101. [CrossRef] [PubMed] 
158. Jones, D.O.B.; Kaiser, S.; Sweetman, A.K.; Smith, C.R.; Menot, L.L.; Vink, A.; Clark, M.R. Biological responses to disturbance from simulated deep-sea polymetallic nodule mining. PLoS ONE 2017, 12, e0171750. [CrossRef]

159. Simon-Lledó, E.; Bett, B.J.; Huvenne, V.A.I.; Schoening, T.; Benoist, N.M.A.; Jeffreys, R.M.; Durden, J.M.; Jones, D.O.B. Megafaunal variation in the abyssal landscape of the Clarion Clipperton Zone. Prog. Oceanogr. 2019, 170, 119-133. [CrossRef]

160. Cuvelier, D.; Gollner, S.; Jones, D.O.B.; Kaiser, S.; Arbizu, P.M.; Menzel, L.; Colaço, A. Potential mitigation and restoration actions in ecosystems impacted by seabed mining. Front. Mar. Sci. 2018, 5, 467. [CrossRef]

161. Wakefield, J.R.; Myers, K. Social cost benefit analysis for deep-sea minerals mining. Mar. Policy 2018, 95, 346-355. [CrossRef]

162. Durden, J.M.; Bett, B.J.; Ruhl, H.A. Subtle variation in abyssal terrain induces significant change in benthic megafaunal abundance, diversity, and community structure. Prog. Oceanogr. 2020, 186, 102395. [CrossRef]

163. Levin, L.A.; Mengerink, K.; Gjerde, K.M.; Rowden, A.A.; Van Dover, C.L.; Clark, M.R.; Ramirez-Llodra, E.; Currie, B.; Smith, C.R.; Sato, K.N.; et al. Marine Policy Defining "serious harm" to the marine environment in the context of deep seabed mining. Mar. Policy 2016, 74, 245-259. [CrossRef]

164. Drazen, J.C.; Smith, C.R.; Gjerde, K.M.; Haddock, S.H.D.; Carter, S.; Choy, C.A.; Clark, M.R.; Dutrieux, P.; Goetze, E.; Hauton, C.; et al. Opinion: Midwater ecosystems must be considered when evaluating environmental risks of deep-sea mining. Proc. Natl. Acad. Sci. USA 2020, 117, 17455-17460. [CrossRef]

165. Veillette, J.; Sarrazin, J.; Gooday, A.J.; Galéron, J.; Caprais, J.C.; Vangriesheim, A.; Étoubleau, J.; Christian, J.R.; Juniper, S.K. Ferromanganese nodule fauna in the tropical North Pacific Ocean: Species richness, faunal cover and spatial distribution. Deep Sea Res. Part II Top. Stud. Oceanogr. 2007, 54, 1912-1935. [CrossRef]

166. Clark, M.R. Biology associated with Cobalt-rich Ferromanganese crusts. In Deep Sea Minerals: Cobalt-Rich Ferromanganese Crusts, a Physical, Biological, Environmental, and Technical Review; Baker, E., Beaudoin, Y., Eds.; SPC: Noumea, New Caledonia, France, 2013.

167. Vanreusel, A.; Hilario, A.; Ribeiro, P.A.; Menot, L.; Martinéz Arbizu, P. Threatened by mining, polymetallic nodules are required to preserve abyssal epifauna. Sci. Rep. 2016, 6, 26808. [CrossRef]

168. Boschen, R.E.; Rowden, A.A.; Clark, M.R.; Gardner, J.P.A. Mining of deep-sea seafloor massive sulfides: A review of the deposits, their benthic communities, impacts from mining, regulatory frameworks and management strategies. Ocean Coast. Manag. 2013, 84, 54-67. [CrossRef]

169. Koschinsky, A.; Hein, J.R.; Kraemer, D.L.; Foster, A.L.; Kuhn, T.; Halbach, P. Platinum enrichment and phase associations in marine ferromanganese crusts and nodules based on a multi-method approach. Chem. Geol. 2020, 539, 119426. [CrossRef]

170. Suzuki, K.; Yoshida, K.; Watanabe, H.; Yamamoto, H. Mapping the resilience of chemo- synthetic communities in hydrothermal vent fields. Sci. Rep. 2018, 8, 9364. [CrossRef] [PubMed]

171. Urabe, T.; Ura, T.; Tsujimoto, T.; Hotta, H. Next-generation technology for ocean resources exploration (Zipangu-in-the-Ocean) project in Japan. In OCEANS 2015-Genova; IEEE: Manhattan, NY, USA, 2015.

172. Dick, G.J.; Anantharaman, K.; Baker, B.J.; Li, M.; Reed, D.C.; Sheik, C.S. The microbiology of deep-sea hydrothermal vent plumes: Ecological and biogeographic linkages to seafloor and water column habitats. Front. Microbiol. 2013, 4, 124. [CrossRef]

173. Van Dover, C.L. Inactive sulfide ecosystems in the deep sea: A review. Front. Mar. Sci. 2019, 6, 461. [CrossRef]

174. Purser, A.; Marcon, Y.; Hoving, H.-J.T.; Vecchione, M.; Piatkowski, U.; Eason, D.; Bluhm, H.; Boetius, A. Association of deep-sea incirrate octopods with manganese crusts and nodule fields in the Pacific Ocean. Curr. Biol. 2016, 26, R1247-R1271. [CrossRef]

175. Le, J.T.; Levin, L.A.; Carson, R.T. Deep-Sea Research II Incorporating ecosystem services into environmental management of deep-seabed mining. Deep Sea Res. Part II 2017, 137, 486-503. [CrossRef]

176. Krupp, F. ; Horn., N. Earth: The Sequel. The Race to Reinvent Energy and Stop Global Warming; Norton and Company: New York, NY, USA, 2008; p. 288.

177. Taormina, B.; Laurans, M.; Marzloff, M.P.; Dufournaud, N.; Lejart, M.; Desroy, N.; Leroy, D.; Martin, S.; Carlier, A. Renewable energy homes for marine life: Habitat potential of a tidal energy project for benthic megafauna. Mar. Environ. Res. 2020, 161, 105131. [CrossRef]

178. Dannheim, J.; Bergström, L.; Birchenough, S.N.R.; Brzana, R.; Boon, A.R.; Coolen, J.W.P.; Dauvin, J.-C.; Degraer, S. Benthic effects of offshore renewables: Identification of knowledge gaps and urgently needed research. ICES J. Mar. Sci. 2019, 77, 1092-1108. [CrossRef]

179. Boehlert, G.W.; Gill, A.B. Environmental and ecological effects of ocean renewable energy development: A current synthesis. Oceanography 2010, 23, 68-81. [CrossRef]

180. Copping, K.J.; Accioly, J.M.; Deland, M.P.B.; Edwards, N.J.; Graham, J.F.; Hebart, M.L.; Pitchford, W.S. Divergent genotypes for fatness or residual feed intake in Angus cattle. 3. Performance of mature cows. Anim. Prod. Sci. 2016, 58, 55-66. [CrossRef]

181. Neo, Y.Y.; Seitz, J.; Kastelein, R.A.; Winter, H.V.; Ten Cate, C.; Slabbekoorn, H. Temporal structure of sound affects behavioural recovery from noise impact in European seabass. Biol. Conserv. 2014, 178, 65-73. [CrossRef]

182. Coates, D.A.; Van Hoey, G.; Colson, L.; Vincx, M.; Vanaverbeke, J. Rapid macrobenthic recovery after dredging activities in an offshore wind farm in the Belgian part of the North Sea. Hydrobiologia 2015, 756, 3-18. [CrossRef]

183. Burkhard, B.; Opitz, S.; Lenhart, H.-J.; Ahrendt, K.; Garthe, S.; Mendel, B.; Windhorst, W. Ecosystem based modelling and indication of ecological integrity in the German North Sea. Case study offshore wind farms. Ecol. Indic. 2011, 11, 168-174. [CrossRef]

184. Mangi, S.C. The impact of offshore wind farms on marine ecosystems: A review taking an ecosystem services perspective. Proc. IEEE 2013, 101, 999-1009. [CrossRef] 
185. Bergström, L.; Kautsky, L.; Malm, T.; Ohlsson, H.; Wahlberg, M.; Rosenberg, R.; Capetillo, N.Å. The Effects of Wind Power on Marine Life: A Synthesis; Swedish Environmental Protection Agency: Stockholm, Sweden, 2012; ISBN 978-91-620-6512-6.

186. Bahrman, M.P.; Johnson, B.K. The ABCs of HVDC transmission technologies. IEEE Power Energy Mag. 2007, 5, 32-44. [CrossRef]

187. de Vries, E.; Milborrow, D.; Staffell, I. Wind turbine trends. ENDS Intell. 2017. Available online: https:/ /www.windpowermonthly. com/article/1595917/wind-turbine-trends (accessed on 20 April 2021).

188. Ryndzionek, R.; Sienkiewicz, Ł. Evolution of the HVDC Link Connecting Offshore Wind Farms to Onshore Power Systems. Energies 2020, 13, 1914. [CrossRef]

189. Carr-Harris, A.; Lang, C. Sustainability and tourism: The effect of the United States' first offshore wind farm on the vacation rental market. Resour. Energy Econ. 2019, 57, 51-67. [CrossRef]

190. Albrecht, C.; Wagner, A.; Wesselmann, K.; Korb, M. The Impact of Offshore Wind Energy on Tourism. Good Practices and Perspectives for the South Baltic Region. 2013. Available online: https://www.offshore-stiftung.de/sites/offshorelink.de/files/ documents/Offshore_Stiftung_2013_04SBO_SOW_tourism_study_final_web.pdf (accessed on 1 August 2021).

191. Glasgow Caledonian University. Economic Impacts of Wind Farms on Scottish Tourism: Research Findings; 2008 ; ISBN 9780755970322. Available online: https://www.gov.scot/publications/economic-research-findings-economic-impacts-wind-farms-scottishtourism/documents / (accessed on 18 March 2021).

192. Cherif, E.K.; Vodopivec, M.; Mejjad, N.; Da Silva, J.C.G.E.; Simonovič, S.; Boulaassal, H. COVID-19 Pandemic Consequences on Coastal Water Quality Using WST Sentinel-3 Data: Case of Tangier, Morocco. Water 2020, 12, 2638. [CrossRef]

193. Mejjad, N.; Laissaoui, A.; El-Hammoumi, O.; Fekri, A.; Amsil, H.; El-Yahyaoui, A.; Benkdad, A. Geochemical, radiometric, and environmental approaches for the assessment of the intensity and chronology of metal contamination in the sediment cores from Oualidia lagoon (Morocco). Environ. Sci. Pollut. Res. Int. 2018, 25, 22872-22888. [CrossRef] [PubMed]

194. Ballschmiter, K.H.; Froescheis, O.; Jarman, W.M.; Caillet, G. Contamination of the deep-sea. Mar. Pollut. Bull. 1997, 34, 288-289. [CrossRef]

195. Benmhammed, A.; Laissaoui, A.; Mejjad, N.; Ziad, N.; Chakir, E.; Benkdad, A.; Ait Bouh, H.; El Yahyaoui, A. Recent pollution records in Sidi Moussa coastal lagoon (western Morocco) inferred from sediment radiometric dating. J. Environ. Radioact. 2020, 227, 106464. [CrossRef] [PubMed]

196. Mejjad, N.; El-Hammoumi, O.; Fekri, A.; Laissaoui, A.; Benmansour, M.; Bounouira, H.; Benkdad, A.; Bounakhla, M.; Benbrahim, S.; Bouthir, F.Z. Sediment geochronology and geochemical behavior of major and rare earth elements in the Oualidia Lagoon in the western Morocco. J. Radioanal. Nucl. Chem. 2016, 309, 1133-1143. [CrossRef]

197. Arrieta, J.M.; Arnaud-Haond, S.; Duarte, C.M. What lies underneath: Conserving the oceans' genetic resources. Proc. Natl. Acad. Sci. USA 2010, 107, 18318-18324. [CrossRef]

198. Deming, J.W. Deep ocean environmental biotechnology. Curr. Opin. Biotechnol. 1998, 9, 283-287. [CrossRef]

199. Leary, D.K. International Law and the Genetic Resources of the Deep Sea; Martinus Nijh off Publishers: Lejda, The Netherlands, 2007; p. 56.

200. Fingerman, M. Recent Advances in Marine Biotechnology, Volume 8: Bioremediation; CRC Press: Boca Raton, FL, USA, 2003 ; p. 8.

201. Mapelli, F.; Scoma, A.; Michoud, G.; Aulenta, F.; Boon, N.; Borin, S.; Daffonchio, D. Biotechnologies for marine oil spill cleanup: Indissoluble ties with microorganisms. Trends Biotechnol. 2017, 35, 860-870. [CrossRef] 